\title{
Primary Immune Thrombocytopenia: Novel Insights into Pathophysiology and Disease Management
}

\author{
Anurag Singh ${ }^{1,+(\mathbb{D})}$, Günalp Uzun ${ }^{2,+}$ (D) and Tamam Bakchoul $1,2, *$ (D) \\ 1 Institute for Clinical and Experimental Transfusion Medicine (IKET), University Hospital of Tuebingen, \\ 72076 Tuebingen, Germany; anurag.singh@med.uni-tuebingen.de \\ 2 Centre for Clinical Transfusion Medicine, University Hospital of Tuebingen, 72076 Tuebingen, Germany; \\ guenalp.uzun@med.uni-tuebingen.de \\ * Correspondence: tamam.bakchoul@med.uni-tuebingen.de; Tel.: +49-7071-29-81601 \\ + These authors contributed equally to this work.
}

Citation: Singh, A.; Uzun, G.; Bakchoul, T. Primary Immune Thrombocytopenia: Novel Insights into Pathophysiology and Disease Management. J. Clin. Med. 2021, 10, 789. https://doi.org/10.3390/ jcm10040789

Academic Editor: Hugo ten Cate Received: 15 January 2021

Accepted: 10 February 2021

Published: 16 February 2021

Publisher's Note: MDPI stays neutral with regard to jurisdictional claims in published maps and institutional affiliations.

Copyright: (c) 2021 by the authors. Licensee MDPI, Basel, Switzerland. This article is an open access article distributed under the terms and conditions of the Creative Commons Attribution (CC BY) license (https:/ / creativecommons.org/licenses/by/ $4.0 /)$.

\begin{abstract}
Immune thrombocytopenia (ITP) is an autoimmune disorder defined by a significantly reduced number of platelets in blood circulation. Due to low levels of platelets, ITP is associated with frequent bruising and bleeding. Current evidence suggests that low platelet counts in ITP are the result of multiple factors, including impaired thrombopoiesis and variations in immune response leading to platelet destruction during pathological conditions. Patient outcomes as well as clinic presentation of the disease have largely been shown to be case-specific, hinting towards ITP rather being a group of clinical conditions sharing common symptoms. The most frequent characteristics include dysfunction in primary haemostasis and loss of immune tolerance towards platelet as well as megakaryocyte antigens. This heterogeneity in patient population and characteristics make it challenging for the clinicians to choose appropriate therapeutic regimen. Therefore, it is vital to understand the pathomechanisms behind the disease and to consider various factors including patient age, platelet count levels, co-morbidities and patient preferences before initiating therapy. This review summarizes recent developments in the pathophysiology of ITP and provides a comprehensive overview of current therapeutic strategies as well as potential future drugs for the management of ITP.
\end{abstract}

Keywords: immune thrombocytopenia; bleeding; platelets; platelet destruction; immune tolerance; megakaryocytes; ITP treatment

\section{Introduction}

Primary immune thrombocytopenia (ITP) is a haematological autoimmune disorder characterised by bleeding and a low platelet count of less than $100 \times 10^{9} / \mathrm{L}$ [1-4]. There are several factors contributing to the onset of ITP, and the exact mechanisms behind how host immune response turns against own system (autoimmunity) and leads to ITP are still incompletely understood. There is growing evidence suggesting that the main event during ITP is a misbalanced interaction between effectors and regulatory immune cells [5]. This lack of an equitable response leads to a distorted immune tolerance, resulting in increased platelet clearance by immune cells, as well as an impairment in thrombopoiesis. Earlier studies suggested that a low platelet count is largely a consequence of anti-platelet antibodies opsonizing the cells and hence an increased clearance from the circulation [6-8]. However, lately, it has been demonstrated by many researchers that cytotoxic $\mathrm{T}$ cells also play a vital role in ITP pathomechanism by impairing megakaryopoiesis.

During ITP, it has been observed that although brief, spontaneous remissions can occur frequently in children. On the other hand, adult patients rather display a more chronic form of ITP that correlates with significant clinical presentations including bleeding disorders, haemorrhages in skin or mucous membranes, namely purpura, petechiae and rarely intracranial manifestations of the disease $[9,10]$. Treatment strategies for ITP 
are mostly prescribed on the basis of clinical symptoms of the patients with a focus on reducing the risk of severe bleeding, and they do not essentially include the boosting of platelet numbers. As per the guidelines of International Working Group [2,11], patients with acute ITP and without a history suggesting severe bleeding risk are advised to be managed with observation strategy (wait and see). On the other hand, ITP patients require urgent treatment if they are prone to a higher risk of bleeding or carry a severe case of chronic thrombocytopenia.

In this review, we discuss the pathomechanisms that lead to platelet destruction in ITP with a particular focus on recent findings regarding various diversifications during thrombopoiesis. Furthermore, we will provide a broad overview regarding various management strategies of ITP patients. We also outline different treatment options including efficacy and safety of therapeutic medicaments, management of bleeding emergencies as well as a summary of different approved drugs as well as drugs under clinical trials for ITP treatment.

\section{Pathophysiology of ITP}

One of the crucial steps during pathophysiology of ITP is described as the loss of immunological tolerance to autoantigens on patient's own platelets [12]. Many studies demonstrate that during ITP, a dysregulated T-cell response leads to a distorted balance of helper T cells (Th1/Th2) ratio [13,14], and imbalance further leads to an enhanced number as well as hyperactivity of cytotoxic $T$ cells. Subsequently, this enhanced activity of cytotoxic $T$ cells results in an increase in platelet destruction, combined with improved survival of B cells. An enhanced survival rate of B cells hence facilitates a larger production of autoantibodies, leading to an accelerated rate of platelet clearance. Autoantibodies opsonize platelets leading to enhanced phagocytosis, apoptosis, complement activation and impaired thrombopoiesis [15-17] (Figure 1).

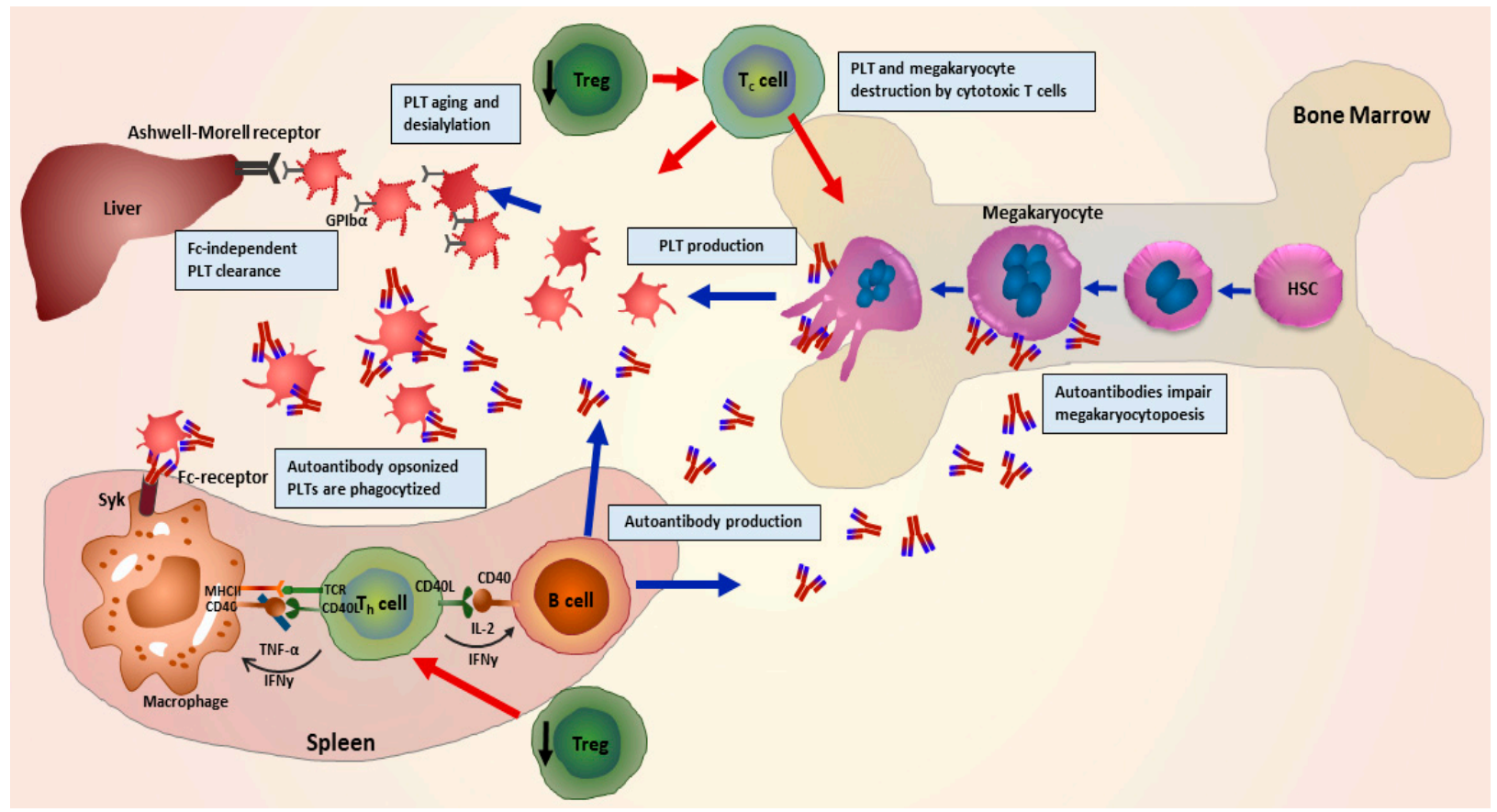

Figure 1. Graphical representation of the pathophysiology of immune thrombocytopenia (ITP) illustrating involvement of multiple immune cells. Impairment of regulatory T cells leads to a disruption in regulation of helper T cell-mediated activation of B cells. B cells in turn produce autoantibodies in abundance leading to opsonisation, phagocytosis and complement activation, desialylation and finally destruction of platelets. Autoantibodies further hinder megakaryocyte maturation (megakaryocytopoiesis), and autoreactive cytotoxic T cells destroy megakaryocytes and platelets. (Adapted from Kashiwagi et al. 2013 [18]). 
Although platelet destruction in the spleen primarily involves constant fragment (Fc)-dependent mechanisms, various researchers have also described novel mechanisms independent of Fc-mediation [19-21]. In a study, it was shown that ITP-autoantibodies can induce glycan modifications on platelet surface glycoproteins (GPs). Upon further recognition by Ashwell-Morell receptors which are expressed on hepatocytes, this GPs modification leads to accelerated platelet clearance in the liver [22]. CD8+ T cells from ITP patients also induce platelet desialylation and platelet phagocytosis by hepatocytes [23]. This might explain a potential mechanism how splenectomy remains ineffective in some ITP patients. In an intriguing retrospective study with a cohort of 61 ITP patients, it was shown that platelet desialylation and subsequent reduction in response to first line of treatments was independent of any Fc-mediated mechanism [24].

A recent study by Quach and colleagues demonstrated that ITP patients who did not respond to therapy were more likely to produce autoantibodies against the ligand binding domain (LBD) of GPlb/1X [25]. This specific binding leads to activation of GPIb/IX via crosslinking of platelet receptors and unfolding of a mechanosensory domain and platelet destruction, providing further a pivotal evidence of Fc-independent mechanism [25]. Recently, we demonstrated that novel effector functions of autoantibodies in ITP modulate the disease and might interfere with the clinical outcome for patients. We showed that a subgroup of autoantibodies induces cleavage of sialic acid residues from the surface of human platelets and megakaryocytes during ITP. Furthermore, autoantibody-mediated desialylation was found to interfere with the cell-extracellular matrix protein interaction and hence leading to impaired platelet adhesion and megakaryocyte differentiation [26]. This hints towards a potential use of sialidase inhibitors as a treatment approach in combination with other therapies to boost platelet numbers in some patients who have failed to respond to previous therapies.

It is well established that intrinsic apoptotic pathway plays a significant role in platelet life cycle. Many research groups have demonstrated the role of ITP-autoantibodies in regulating platelet apoptosis and pathways involved. There is ample evidence showing that various apoptosis markers including phosphatidylserine (PS) exposure, depolarisation of the mitochondrial transmembrane potential, Bcl-2 family protein expression, activation of caspase- 3 as well as of caspase- 9 are significantly involved in platelet apoptosis in ITP $[27,28]$. Immunoglobin infusion was shown to successfully mitigate platelet apoptosis in adult as well as paediatric patients [29,30]. Interestingly, it was shown that apoptotic platelets were not found in ITP patients harbouring anti-GPIa/IIa autoantibodies but only in those who carried anti-GPIIb/IIIa and anti-GPIb autoantibodies [31], indicating a potential role of autoantibody specificity.

Autoantibodies produced during ITP not only affect platelet survival but also platelet formation by megakaryocytes [32]. It has been shown that autoantibodies bind and hinder the megakaryocyte maturation, resulting in reduced platelet formation $[33,34]$. It was demonstrated in vitro, that autoantibodies inhibit platelet production by impairing megakaryopoiesis and maturation [35-37]. However, the role of megakaryocyte apoptosis still needs to be investigated in terms of involvement in the pathophysiology of ITP. There have been some hints and contradicting claims through results generated via earlier and recent investigations. A study in fact demonstrated that treatment with ITP plasma rather leads to a reduced apoptosis of megakaryocytes [38]. Haematopoietic stem cells (HSCs) isolated from healthy umbilical cord blood were co-cultured with plasma of ITP patients, resulting into a decrease in apoptosis, reduced expression of tumour necrosis factor-related apoptosis inducing ligand (TRAIL) and increased expression of the anti-apoptotic protein Bcl-xL in differentiated megakaryocytes [39]. On the other hand, in contrast to these findings, an earlier in vivo study suggested that megakaryocytes in fact undergo enhanced apoptosis in the presence of autoantibodies [40]. It was observed in biopsies of ITP patients that increased apoptosis involves nuclear fragmentation, chromatin condensation and activation of caspase 3 . This further leads to phagocytosis of the polyploid cells by resident macrophages in the bone marrow [40]. Another recent study 
showed that an increased megakaryocyte apoptosis occurs in the bone marrow samples obtained from ITP patients [41].

\section{Clinical Manifestations}

The overall annual incidence rate of ITP is $1.6-5.3$ per 100,000 persons, and it is more frequent in women than men [42-44]. ITP can be classified according to disease duration as acute ( $<3$ months), persistent ( 3 to 12 months) or chronic ( $>12$ months). Compared to children, adults are more likely to develop chronic ITP disease. While up to $60 \%$ of adults develop chronic diseases [45,46], only $20-30 \%$ of children have persistent thrombocytopenia at 12 months [47,48].

Most patients are presented with bleeding symptoms such as petechiae, purpura, haemorrhages of the mucous membranes of the mouth and nose, urogenital bleeding or increased menstrual bleeding [49]. Some patients can be asymptomatic at presentation and $30-40 \%$ of patients with chronic ITP do not have any bleeding symptom [50]. Bleeding risk is calculated as $8 \%$ per year in ITP patients [51].

Major bleedings are associated with a high rate of mortality [52,53]. Reported rates of severe bleeding vary depending on the population studied. In a recent literature review including 108 studies reporting on 10,908 patients, the weighted proportion for intracerebral haemorrhage (ICH) was $1.0 \%$ (95\% CI, $0.7-1.3)$ and for non- $\mathrm{ICH}$ severe bleeding was $15.0 \%$ (95\% CI, 9.3-21.8) [54]. Forsthye and colleagues reported a severe bleeding episode that required rescue medication (intravenous immunoglobulin, corticosteroid injections or platelet transfusions) in 10,2\% of adult ITP patients within 6 months after starting therapy with thrombopoietin receptor agonists (TRO-RA) [55]. In a retrospective evaluation of the McMaster ITP registry, Arnold et al. found that $56 \%$ of ITP patients experience clinically significant bleeding at some point during their disease course and $2.2 \%$ had ICH [56].

Compared to ITP patients with normal platelet counts, those with a platelet count between 25 to $49 \times 10^{9} / \mathrm{L}$ and $<25 \times 10^{9} / \mathrm{L}$ had 2.4 fold and 4.5 fold increased bleeding rates, respectively [51]. Furthermore, bleeding requiring a hospital contact within 1 year prior to ITP diagnosis was associated with a 3-fold increased rate of subsequent bleeding [51]. The use of non-steroidal anti-inflammatory drugs (NSAIDs) was found to be associated with any bleeding (OR 4.8, 95\% CI 1.1-20.7) and anticoagulant drugs were associated with severe bleeding (OR 4.3, 95\% CI 1.3-14.1) [57]. In a large patient cohort, Hato et. al. found that age ( $>60$ years), platelet count $\left(<10 \times 10^{9} / \mathrm{L}\right)$, and the presence of haematuria are associated with increased risk for ICH [58].

Fatigue is common in patients with ITP, and its impact on health-related quality of life in ITP patients has been until recently underappreciated [59]. Treatments that increase platelet count also reduce fatigue $[60,61]$. However, it is also recommended to use treatment strategies that directly target fatigue to improve the health-related quality of life in ITP patients [62].

Paradoxically, an increased frequency of thromboembolic events has been reported in ITP patients $[63,64]$. Therefore, it is crucial that ITP patients should be aware of the risk of thromboembolic events. Patients should be educated that ITP can increase not only the risk of bleeding but also the risk of venous and arterial thromboembolism [50]. Furthermore, patients at risk of embolic events should be followed more closely. Presence of lupus anticoagulants is related to thrombotic events [65]. The increased levels of prothrombotic, platelet-derived microparticles and complement activation on antibody-coated platelets also contribute to the development of thrombosis in ITP [66]. In addition to disease and patient related factors, ITP treatments such as TPO-RA and splenectomy could also increase the individual risk of thromboembolic events $[64,67,68]$. Clinical management of thrombocytopenic patients who require anticoagulant or antiplatelet therapy due to cardiovascular comorbidities is a serious challenge. An aggressive treatment of ITP may be required in these patients to achieve a safe platelet count over $50 \times 10^{9} \mathrm{~L}$ [50].

The overall mortality rate is slightly higher than general population in ITP patients, predominantly due to increased cardiovascular disease, infection, bleeding and haematological cancer related mortalities [69]. 


\section{Diagnosis}

ITP is usually diagnosed after precluding other potential causes of thrombocytopenia. A diagnosis is performed in patients with a low platelet count $\left(<10010^{9} / \mathrm{L}\right)$ with no evidence or history of an underlying condition, which can lead to thrombocytopenia, including a physical examination, evaluation of blood counts and visual examination of blood smears. However, since thrombocytopenia may be a multifactorial condition, it is indeed complicated to identity substitute causes, and examining physician needs to have a broad knowledge in platelet disorders. A confirmation of ITP is achieved via detection of characteristic platelet-specific autoantibodies, free in patient serum or bound to own platelets [70]. As per recommendations of various regulatory guidelines, GP-specific assays, for example direct monoclonal antibody immobilisation of platelet antigens (MAIPA test) or direct immunobead assays prove the diagnosis of ITP, and further laboratory tests are deemed unnecessary [71]. However, current ASH-guidelines of 2019 do not give any clear recommendations for antibody evaluation in ITP patients, as there is still lack of strong evidence supporting clinical advantage of the assays [4]. We strongly recommended that as a part of initial assessment, presence of platelet autoantibodies should be evaluated. A positive test result at this stage establishes a sound basis for further diagnostic procedures and paves ways for initiating the treatment. It is notable to mention that although GPspecific tests have shown an excellent specificity, the lack of sensitivity is an important issue to consider. The low sensitivity of the test can often produce negative results, and care needs to be taken while interpretation and subsequent recommendation. Other potential hurdles in implementing antibody testing as a part of mandatory diagnostic regime for ITP also include unavailability of experienced staff, equipment and set up, as well as cost effectiveness.

Therefore, it is recommended to establish an appropriate diagnostic set up to analyse ITP during early phase of patient examination.

\section{Treatment of ITP}

The main goals of ITP treatment are to intervene in the case of an acute severe bleeding and to prevent future bleeding events (Figure 2).

\subsection{First-Line Treatments and Treatment of Bleeding Emergencies}

The decision to start a treatment in newly diagnosed ITP depends on several factors. Current guidelines recommend a platelet count of 20 to $30 \times 10^{3} / \mu \mathrm{L}$ as a cut-off value to start intervention in adult ITP patients [4]. Other than thrombocyte count, patient related factors can help to determine the risk of bleeding such as age (e.g., >65 years), previous bleeding events, comorbidities associated with high bleeding risk (i.e., hypertension, cerebrovascular disease), renal or hepatic impairment, medication with anticoagulants and platelet inhibitors, surgical interventions and risky life style (i.e., combat sports) $[51,57,73]$. A higher platelet count $(>50,000 \mu \mathrm{L})$ should be considered for these patient populations.

As emphasized in the current guidelines, the decision regarding ITP treatment should be made in agreement between physician and patient. The patient should be informed about the benefits and possible side effects of treatment options. It should be considered that some side effects of treatments might pose a greater risk for the patient than ITP itself [74]. Advantages and disadvantages of ITP treatments are summarized in Table 1. 


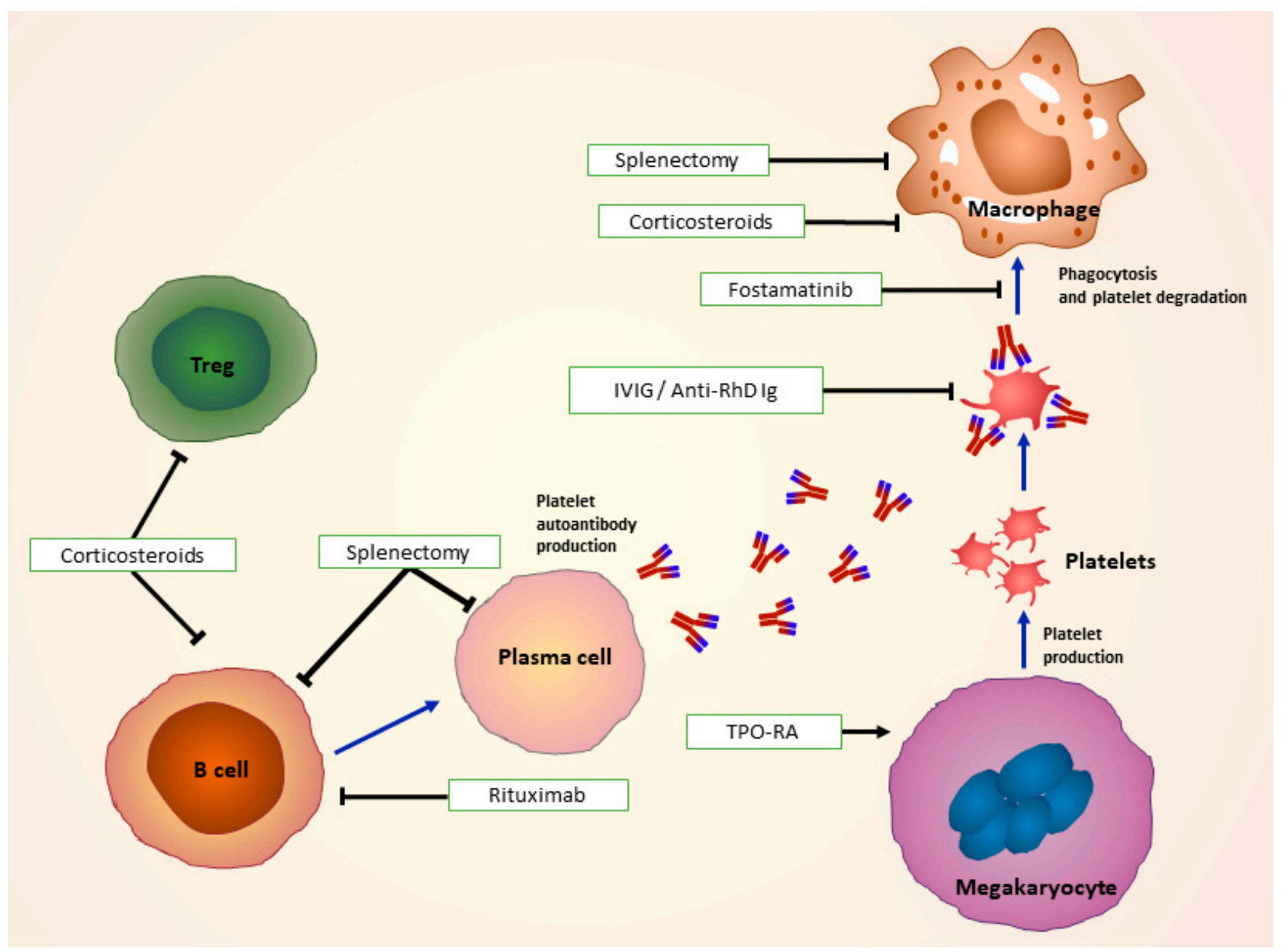

Figure 2. Treatments for immune thrombocytopenia: Corticosteroids used as first line of treatment modulate Treg, B-cell and FCR function. In combination with or without IVIg and anti-D, they impair antigen presentation and recognition of autoantibody-coated platelets by macrophages. Second-line treatments such as surgical splenectomy remove spleen as a site of platelet destruction, and drugs as rituximab target antibody-producing B cells. TPO-RAs, such as romiplostim and eltrombopag work by stimulating platelet production by megakaryocytes. Fostamatinib impairs Syk-mediated phagocytosis of platelets. FcR: Fc receptors; IVIg: Intravenous immunoglobulin; TPO-RA: Thrombopoietin receptor agonist; Syk: spleen tyrosine kinase. (Adapted from Newland et al. 2018 [72]).

Table 1. Treatment options for ITP.

\begin{tabular}{|c|c|c|c|}
\hline Agent & Application Route and Dosage & Advantages & Disadvantages and Complications \\
\hline \multicolumn{4}{|l|}{ First-line Therapies } \\
\hline \multicolumn{4}{|l|}{ Glucocorticoids } \\
\hline Predniso(lo)ne & $\begin{array}{c}\text { Oral } \\
1 \mathrm{mg} / \mathrm{kg} \text { of body weight for } \\
2-3 \text { weeks (maximum } 80 \mathrm{mg} / \mathrm{d} \text { ), } \\
\text { gradual tapering } \\
\text { Oral } \\
40 \mathrm{mg} \text { for } 4 \text { days } \\
\text { Maximum } 3 \text { cycles }\end{array}$ & $\begin{array}{l}\text { Response within } 1-2 \text { weeks } \\
\text { Early response rate } 60-80 \%\end{array}$ & $\begin{array}{l}\text { Low durable response rate after discontinuation } \\
\qquad(30-50 \%) \\
\text { Complications: hypertension, hyperglycaemia, } \\
\text { sleep and mood disturbances, gastric ulceration, } \\
\text { myopathy, glaucoma and osteoporosis }\end{array}$ \\
\hline Immunoglobulin & $\begin{array}{c}\text { Intravenous } \\
0.4-1 \mathrm{gr} / \mathrm{kg} \text { of body weight, total } \\
\text { maximal dose of } 2 \mathrm{gr} / \mathrm{kg} \text { of } \\
\text { body weight }\end{array}$ & $\begin{array}{l}\text { Response within } 1-4 \text { days } \\
\text { Early response rate } 70-80 \%\end{array}$ & $\begin{array}{l}\text { Only a transient rise of platelet count } \\
\text { Complications: headache, pyrexia, vomiting, } \\
\text { acute kidney injury, aseptic meningitis and } \\
\text { thrombotic events }\end{array}$ \\
\hline Anti-Rhesus D Ig & $\begin{array}{l}\text { Intravenous } \\
50 \text { to } 75 \mu \mathrm{g} / \mathrm{kg}\end{array}$ & Early response rate $65 \%$ & $\begin{array}{c}\text { Only effective in Rh-positive patients } \\
\text { Not approved for ITP in Europe } \\
\text { Complications: headache, nausea, chills, fever } \\
\text { and mild to moderate haemolysis } \\
\text { Severe intravascular haemolysis and } \\
\text { disseminated intravascular coagulation }\end{array}$ \\
\hline
\end{tabular}


Table 1. Cont.

\begin{tabular}{|c|c|c|c|}
\hline Agent & $\begin{array}{c}\text { Application Route and } \\
\text { Dosage }\end{array}$ & Advantages & Disadvantages and Complications \\
\hline \multicolumn{4}{|l|}{$\begin{array}{l}\text { Second-line } \\
\text { Therapies }\end{array}$} \\
\hline \multicolumn{4}{|l|}{$\begin{array}{l}\text { Thrombopoietin- } \\
\text { receptor } \\
\text { Agonists }\end{array}$} \\
\hline Romiplostim & $\begin{array}{c}\text { Subcutaneous } \\
1-10 \mathrm{microg} / \mathrm{kg} / \text { week }\end{array}$ & $\begin{array}{l}\text { Response rate } 70-80 \% \\
\text { Remission rate } 10-30 \%\end{array}$ & $\begin{array}{c}\text { Cost } \\
\text { Headache, arthralgia, myalgia, dizziness } \\
\text { and insomnia } \\
\text { Thromboembolism and bone } \\
\text { marrow fibrosis } \\
\text { Cost }\end{array}$ \\
\hline Eltrombobag & $\begin{array}{c}\text { Oral } \\
25-75 \mathrm{mg} / \text { day }\end{array}$ & $\begin{array}{l}\text { Response rate } 70-80 \% \\
\text { Remission rate } 10-30 \%\end{array}$ & $\begin{array}{c}\text { Dietary restrictions } \\
\text { Gastrointestinal symptoms (nausea, } \\
\text { vomiting, diarrhoea), mild transaminase } \\
\text { elevations and headache } \\
\text { Thromboembolism and bone } \\
\text { marrow fibrosis }\end{array}$ \\
\hline Avatrombopag & $\begin{array}{c}\text { Oral } \\
20-40 \mathrm{mg} / \text { day }\end{array}$ & $\begin{array}{c}\text { Response rate } 60 \% \\
\text { No dietary restrictions }\end{array}$ & $\begin{array}{l}\text { Headache, arthralgia, fatigue } \\
\text { and diarrhoea }\end{array}$ \\
\hline \multicolumn{4}{|c|}{ Immunomodulators } \\
\hline Rituximab & $\begin{array}{c}\text { Intravenous } \\
375 \mathrm{mg} / \mathrm{m}^{2} \text { per week for } 4 \\
\text { weeks } \\
100 \mathrm{mg} / \mathrm{m}^{2} \text { per week for } 4 \\
\text { weeks }\end{array}$ & $\begin{array}{l}\text { Response rate } 60 \% \text { at } 6 \\
\text { months } \\
\text { No need for chronic } \\
\text { treatment }\end{array}$ & $\begin{array}{c}\text { High relapse rate } \\
\text { Contraindicated by patients with evidence } \\
\text { of an active or previous HBV infection } \\
\text { Increased tendency to minor infections; } \\
\text { progressive multifocal } \\
\text { leukoencephalopathy }\end{array}$ \\
\hline Fostamatinib & $\begin{array}{c}\text { Oral } \\
100-150 \mathrm{mg} \text { twice daily }\end{array}$ & $\begin{array}{l}\text { Response rate } 43 \% \text { within } \\
12 \text { weeks after treatment }\end{array}$ & $\begin{array}{l}\text { Diarrhoea, hypertension and nausea } \\
\text { Monthly follow up for hypertension, } \\
\text { hepatotoxicity and neutropenia. }\end{array}$ \\
\hline Splenectomy & Open or laparoscopic surgery & $\begin{array}{l}\text { Durable remission rate } 60 \\
\text { to } 70 \% \\
\text { No need for chronic } \\
\text { treatment }\end{array}$ & $\begin{array}{l}\text { Surgical complications, thromboembolic } \\
\text { events, infection with encapsulated } \\
\text { bacteria, Sepsis }\end{array}$ \\
\hline
\end{tabular}

\subsubsection{Glucocorticoids}

Glucocorticoid treatment is the most-commonly used first-line therapy in patients with ITP $[43,75]$. The beneficial effects of glucocorticoids include reduction of platelet clearance by reticuloendothelial system [76,77]. Platelet count usually increases within a couple of days after therapy initiation [49]. Two most-commonly used glucocorticoids are prednisone $(1 \mathrm{mg} / \mathrm{kg}$ orally per day for 2-3 weeks, with a gradual withdraw and discontinuation by 6 to 8 weeks) and high-dose dexamethasone (one or more cycles of $40 \mathrm{mg}$ orally, once daily for 4 days, usually 4 weeks apart) [78]. Current ASH guideline recommends against the use of glucocorticoids longer than 6 weeks [4]. On the other hand, some others suggested that a longer low-dose steroid therapy could be considered to keep the platelet counts over $30 \times 10^{3} / \mathrm{ml}$ if a response with initial steroid therapy has been achieved [11]. Several studies demonstrated more rapid response with dexamethasone as compared to prednisone, but overall response rates are not significantly different in the long term after 6 and 12 months [79]. Similarly, Wang et al. reported a rapid response with high-dose dexamethasone compared to prednisolone, but sustained response rates were similar at 12 months and later [78]. Of note, dexamethasone seems to have a better 
safety profile (fewer Cushing's disease, weight gain and infection rates) in comparison to prednisolone [80].

Despite the high early-response rate, most of the patients do not have a sustained response after the cessation of glucocorticoids. In fact, approximately $80 \%$ of patients respond initially to corticosteroids, but only 20 to $40 \%$ of these patients achieve sustained response when steroids are discontinued $[81,82]$. As a predictive factor, Wang et al. measured anti-platelet antibody levels in ITP patients under glucocorticoid treatment [78]. They found that presence of anti-GPIb-IX antibodies predicts a poor initial response to corticosteroids [78]. Further studies are needed to determine the role of antiplatelet antibodies in predicting the corticosteroid response.

It is crucial to closely monitor the patients for possible side-effects of glucocorticoids such as hypertension, hyperglycaemia, sleep and mood disturbances, gastric ulceration, myopathy, glaucoma and osteoporosis [4]. To prevent severe toxicities, corticosteroids should be tapered appropriately and discontinued in non-responding patients. Nonresponders and patients with contraindication to steroid therapy such as (pregnancy, diabetes mellitus, active infection and psychiatric disorders) can be treated with other first-line treatments-IVIG and IV anti-D [4].

To increase the rate of sustained response, combination of dexamethasone with second line treatments such as rituximab have been investigated. A recent meta-analysis compared the effectiveness of the combination of high-dose dexamethasone and rituximab with dexamethasone alone in ITP [83]. Overall response rate at month 3 (RR $=5.07,95 \% \mathrm{CI}$ : 2.91-8.86, and $p<0.00001)$ and sustained response rate at 12 months ( $R R=1.73,95 \% \mathrm{CI}$ : $1.36-2.91$, and $p<0.00001$ ) was significantly higher in combination arm than that in monotherapy. Furthermore, the rate of adverse events has not significantly increased with combination therapy [83].

\subsubsection{Intravenous Immunoglobulin (IVIG)}

IVIG has been introduced into the treatment of ITP in 1980s [84]. IVIG is prepared by purification from the pooled plasma of healthy donors [84]. It contains polyvalent IgG (80 to $>95 \%$ ) and irrelevant amount of IgA and IgM. IVIG is thought to inhibit Fcmediated phagocytosis of antibody coated platelets by reticuloendothelial system [85]. Platelet count usually increases within 48 hours after IVIG application [86]. The preferred treatment regime is $1 \mathrm{~g} / \mathrm{kg}$ per day, which should be repeated for two consecutive days [2]. A lower dose of $0.2-0.4 \mathrm{~g} / \mathrm{kg} /$ day can also be used for $4-5$ days [87]. In a meta-analysis of 13 randomized studies, low dose IVIG regimes were found to be as effective as high dose IVIG, and low-dose-IVIG was associated with a significantly reduced risk of side-effects $(\mathrm{OR}=0.39(95 \% \mathrm{CI}=0.18-0.83)$ [88].

Limited number of randomized controlled studies compared the effectiveness of IVIG and corticosteroids as a first line therapy in ITP in adults [89,90]. Godeau et al. demonstrated that IVIG increases platelet count more effectively than high-dose methylprednisolone in adults with newly diagnosed ITP (79\% vs. $60 \%$ response rate) [90]. In a smaller study, adult ITP patients were treated with oral prednisone $(1 \mathrm{mg} / \mathrm{kg} /$ day; $n=17)$, high-dose IVIG ( $400 \mathrm{mg} / \mathrm{kg}$ on days 1 through $5 ; n=13$ ) or a combination of both agents $(n=13)$. A platelet response $\left(>50 \times 10^{9} / \mathrm{L}\right)$ was achieved in $82 \%, 54 \%$ and $92 \%$ of patients, respectively [89].

There may be a relationship between the presence of anti-platelet antibody and the response to IVIG. Peng et al. found that the response rate was significantly higher in patients without anti-GPIb-IX autoantibodies compared to those with anti-GPIb-IX autoantibodies ( $80.0 \%$ vs. $36.4 \%$ ), while the presence of the anti-GPIIb/IIIa autoantibodies had no effect on response to treatment [91]. However, others failed to show a significant relationship between an autoantibody and nonresponse to IVIG [92].

Most frequent adverse effects of IVIG include headache, pyrexia and vomiting [93]. Severe side effects such as acute kidney injury, aseptic meningitis and thrombotic events are rare [94]. 


\subsubsection{Anti-RhD Immunoglobulin (Ig)}

Anti-RhD consists of IgG selectively taken from the plasma of donors immunized to the Rhesus D antigen [85]. Anti-RhD Ig binds to Rh-positive erythrocytes and these antibody-coated erythrocytes competitively inhibit the destruction of antibody-coated platelets by binding and occupying Fc receptors on phagocytes in the spleen [95]. Anti-RhD is therefore only effective in Rh-positive patients with an intact spleen. A single intravenous dose of 50 to $75 \mu \mathrm{g} / \mathrm{kg}$ is recommended [96]. A safe subcutaneous administration in small children or patients is also described in the literature [97]. Side effects include mild infusion reactions such as headache, nausea, chills, fever and mild to moderate haemolysis [98]. However, life-threatening episodes of severe intravascular haemolysis and disseminated intravascular coagulation after Anti-RhD Ig administration have also been reported $[99,100]$. These reports led to the withdrawal of an Anti-RhD product (WinRho ${ }^{\circledR}$ SDF, Cangene Europe Ltd, London, UK) from European markets in 2009 [50].

\subsection{Treatment of Active Bleeding}

In case of clinically relevant bleeding, glucocorticoids, IVIG and platelet transfusion are used alone or in combination to increase the platelet count rapidly [11]. Besides, other interventions such as endoscopy or surgery may be necessary depending on the severity and the site of the bleeding [52]. Furthermore, anticoagulant and antiplatelet medications should be ceased immediately, if possible. Since the effect of platelet transfusion is limited due to rapid clearance of platelets by the circulating autoantibodies, combining platelet transfusion with IVIG or corticosteroids might be useful [11]. Although IVIG increases platelet count in most of the cases within 48 hours, its effect is temporary, and platelet count decreases after 1 to 2 weeks. Therefore, concomitant use of glucocorticoids with IVIG can be considered to achieve a more sustained response than that with IVIG alone [90]. Of note, the recommendations for the treatment of active bleeding in ITP are based on small observational studies, and randomized controlled studies are urgently needed.

The Updated International Consensus Report recommends the use of TPO-RA in the case of a life-threatening bleeding if initial treatments with corticosteroids, IVIG and thrombocyte transfusion fails to increase the platelet count [11]. Roumier et al. used high dose romiplostim $(10 \mu \mathrm{g} / \mathrm{kg}$ body weight) together with vinca alkaloids in 30 patients with severe bleeding and compared the results with a historical patient group treated with vinca alkaloids only [101]. Both groups constituted of patients who failed to achieve a response after initial therapy with IVIG, corticosteroids and/or platelet transfusion [101]. At day 7, complete response $(60 \%$ vs. $29 \%, p<0.05)$, and at day 14 , both partial response $(80 \%$ vs. $43 \%, p<0.05)$ and complete response (70 vs. $17 \%, p<0.0001)$ were significantly higher in the romiplostim plus vinca alkaloid group compared to the vinca alkaloid group alone [101]. Although this study shows the effective use of high dose romiplostim in life-threatening bleeding in ITP patients, two patients (6.6\%) treated with high dose romiplostim developed major thromboembolic events. Therefore, the risk over benefit ratio should be carefully assessed for each patient.

Antifibrinolytics (tranexamic acid and aminocaproic acid) are successfully used to control significant bleeding in patients with ITP [102-104]. Oral contraceptives can be used in female patients with menorrhagia. In life threatening bleeding emergencies, recombinant activated factor VII may be a useful supportive treatment [105-107].

\subsection{Second-line treatments}

\subsubsection{Thrombopoietin-Receptor Agonists (TPO-RA)}

Romiplostim is an Fc-peptide fusion protein and administered as a once-weekly subcutaneous injection. The recommended initial dose is $1 \mu \mathrm{g} / \mathrm{kg}$ per week, which can be adjusted by weekly increments of $1 \mu \mathrm{g} / \mathrm{kg}$ according to platelet response to achieve a platelet count of $>50 \times 10^{9}$ platelets $/ \mathrm{L}$. The maximum dose is $10 \mu \mathrm{g} / \mathrm{kg} /$ week. Romiplostim is indicated in adult ITP patients who have had an insufficient response to corticosteroids, immunoglobulins or splenectomy. Self-administration of romiplostim by patients can help 
in reducing healthcare costs and increase patient comfort by eliminating the need to visit the hospital every week for applications [108].

Owing to the effectiveness and safety-profile of TPO-RAs recent studies explored the use of these drugs in other patient groups also. Kuter et al. investigated the effectiveness of romiplostim in patients with ITP for less than 12 months by analysing the data from 9 studies [109]. They found that the number of patients with a platelet response at $\geq 75 \%$ of measurements were higher for romiplostim $(74 \%(204 / 277))$ than for placebo/standard of care $(18 \%(6 / 34))$ in patients with ITP $\leq 1$ year. More importantly the rate of treatment free remission (platelet counts $\geq 50 \times 10^{9} / 1$ for $\geq 6$ months) was higher in patients with ITP $\leq 1$ year compared to those with ITP $>1$ year [109]. Clinically relevant bleeding-related episodes are significantly lower in patients on romiplostim therapy [110,111]. Kuter et al. followed 292 adult ITP patients receiving romiplostim as weekly treatment and observed that the platelet response is maintained with stable dosing for up to 5 years of continuous treatment [67].

Most frequently observed side effects are headache, arthralgia, myalgia, dizziness and insomnia [112]. Thromboembolism and bone marrow fibrosis are the most feared complications of TPO-RA in ITP patients. Gernsheimer reported that romiplostim does not present an increased risk of thromboembolic events compared to placebo [111]. However, close monitoring of patients for thromboembolic events is recommended. Bone marrow changes were observed in a small proportion of patients receiving romiplostim [113]. But the bone marrow fibrosis is reversed after the end of treatment $[114,115]$.

Eltrombopag, which is a synthetic non-peptide molecule, binds selectively with thrombopoietin receptors on megakaryocytes and induces thrombopoiesis [116]. Eltrombopag is recommended for adult ITP patients who have had an insufficient response to corticosteroids, immunoglobulins or splenectomy. Eltrombopag is administered orally as a daily tablet. Daily dose is $25-75 \mathrm{mg}$ according to the age and hepatic function status of the patient. To ensure an adequate absorption of eltrombopag, it should be taken at least 2 hours before or 4 hours after any medications or products containing polyvalent cations (such as antacids, calcium-rich foods and mineral supplements). Many patients have difficulty meeting these dietary requirements and an alternative intermittent dosing 1-5 times weekly have been recommended [117]. Due to the risk of hepatotoxicity, a dose reduction is necessary in patients with hepatic impairment and a close monitoring of liver enzymes and bilirubin every two weeks throughout the treatment is indicated [118].

Randomized controlled studies showed that eltrombopag achieved early platelet response in $70-80 \%$ of the patients and a remission rate of 20-30\% [119-122]. In an openlabel extension study, $85 \%$ of the patients achieved a platelet response, and $52 \%$ of them had a continuous response of 25 weeks or longer [123]. Furthermore, the incidence of bleeding episodes in patients receiving eltrombopag decreased from $57 \%$ to $16 \%$ at 1 year [123]. Although some patients seem to have a prolonged/complete remission after pausing TPORA, no prognostic marker is currently available to identify such patients [124]. However, recently, an inverse relation between TPO level and response to eltrombopag or romiplostim has been shown [125]. Patients with a normal baseline TPO level are more likely to benefit from a therapy with these drugs [125].

Forsthye et al. compared the bleeding related adverse events in patients receiving romiplostim or eltrombopag in a retrospective cross-sectional study. Patients on eltrombopag $(n$ $=1617)$ had significantly fewer bleeding episodes compared to those on romiplostim $(n=$ $1140)(7 \%$ vs. $14 \%)$ [55].

In terms of adverse effects, liver functions, thromboembolism and bone marrow fibrosis have been the areas of concern in the long-term use of eltrombopag [126]. Gastrointestinal symptoms (nausea, vomiting and diarrhoea), mild transaminase elevations and headache are the most commonly observed adverse events in clinical studies [122]. In a prospective safety and efficacy study, thromboembolic events were observed in $6 \%$ of patients and hepatobiliary side effects in $15 \%$ of patients with a median eltrombopag treatment duration of $>2$ years [123]. Regular follow-up of patients for these side effects is justified. 
Avatrombopag is an orally administered TRO-RA and recently received FDA approval for treatment of resistant ITP in adults. Unlike eltrombopag, avatrombopag can be administered without dietary restrictions. Furthermore, avatrombopag does not require monitoring of liver functions [127]. The phase 3 clinical trial showed a longer median number of weeks with platelet count of $50 \times 10^{9} / \mathrm{L}$ or higher during the first 26 weeks in patients who received avatrombopag than in those who received placebo [128]. A platelet response (a platelet count $\geq 30 \times 10^{9} / \mathrm{L}$, with at least a two-fold increase in platelet count from baseline and an absence of bleeding) has been observed in $56.3 \%$ of the avatrombopag treated patients [128]. The recommended initial dose is $20 \mathrm{mg} /$ day. The doses or dosing frequency should be adjusted individually to maintain platelet count greater than $50 \times 10^{9} / \mathrm{L}$. The maximum daily dose is $40 \mathrm{mg}$ [127]. The treatment should be discontinued if a platelet response is not achieved in 4 weeks of avatrombopag therapy at a dose of $40 \mathrm{mg} /$ day. Most common side effects are headache, arthralgia, fatigue and diarrhoea. Further studies are needed to ensure the long-term safety of avatrombopag.

\subsubsection{Immunomodulators}

Rituximab is an anti-CD20 monoclonal antibody that depletes CD20+ B cells and reduces antiplatelet antibody production directly [129]. Rituximab achieves a significantly higher incidence of complete response at 6 months compared to glucocorticoids or placebo in non-splenectomised ITP patients $(46.8 \%$ vs. $32.5 \%)$ [130]. More than one-half of the responders had their response last for at least 1 year, resulting in a 1-year response rate of $38 \%$. Patel et al. reported a 2-year response rate of 31\% and a 5-year response rate of $21 \%$ in adults treated with rituximab [131]. Sustained platelet response lasts more than 2 years in $50 \%$ of patients who have an initial response to rituximab [131,132]. Low dose rituximab therapy has been recommended to avoid treatment related adverse events. A recent systematic review found an overall response rate of $63 \%$ and complete response rate of $44 \%$ in ITP patients treated with low-dose $\left(100 \mathrm{mg}\right.$ or $100 \mathrm{mg} / \mathrm{m}^{2}$ per week for 4 weeks) rituximab instead of the standard dose of $375 \mathrm{mg} / \mathrm{m}^{2}$ per week for 4 weeks [133]. Low dose rituximab has a satisfactory efficacy and safety profile [133]. In a long-term follow-up study (median follow-up of 6 years), median duration of response was longer (17 months vs. 11 months), and splenectomy rate was lower ( $17.2 \%$ vs. 26.4$)$ in rituximab-treated patients. However, $70 \%$ of the rituximab-treated patients relapsed within two years after response [134]. Hammond et al. showed that response rate at 2 years was $70 \%$ in ITP patients treated with rituximab after unsuccessful splenectomy [135]. Wang et al. have recently demonstrated that a positive ANA test is associated with a better initial response but with an unfavourable long-term outcome in ITP patients treated with rituximab [136].

Rituximab should not be prescribed to patients with evidence of an active or previous HBV infection due to the risk of fulminant hepatitis, and other treatment options should be considered [129]. An increased tendency to minor infections after rituximab therapy has been reported. On the other hand, progressive multifocal leukoencephalopathy seem to be rare [137]. Taken together, due to the lower efficacy and higher complications compared with TPO-RAs [138], rituximab should be avoided as first line therapy and used only if there is high evidence for remission [4].

Fostamatinib is an orally available spleen tyrosine kinase (Syk) inhibitor. Syk-dependent phagocytosis of Fc $\gamma$ R-bound platelets plays a role in the pathophysiology of ITP, and fostamatinib inhibits antibody-mediated destruction of platelets [139]. Pooled analyses of two randomized controlled trials demonstrated a response within 12 weeks in $43 \%$ of the patients compared to $14 \%$ of those receiving placebo [140]. In addition, a sustained platelet count $\geq 50 \times 10^{9} / \mathrm{L}$ for up to 24 weeks was observed in $18 \%$ of refractory ITP patients compared to $2 \%$ of those receiving placebo [140]. In the open label extension study with the patients who had a stable response, $21(78 \%)$ patients had maintained the response for 1 year and $15(56 \%)$ for 2 years [141]. In a post-hoc analysis of the phase 3 and open-label extension study, Boccia et al. observed a higher platelet response rate $\left(\geq 50 \times 10^{9} / \mathrm{L}\right)(78 \%$ vs. $48 \%)$ and lower bleeding events ( $28 \%$ vs. $45 \%)$ when fostamatinib was used as a second 
line therapy as compared to its use as a third-or-later-line of therapy [142]. The recommended initial dose is $100 \mathrm{mg}$ twice daily, and the dose can be increased to $150 \mathrm{mg}$ twice daily, if platelet count has not increased to at least $50 \times 10^{9} / \mathrm{L}$ after 4 weeks of therapy. Most common adverse reactions are diarrhoea, hypertension and nausea. A monthly monitoring for hepatotoxicity and neutropenia is recommended [143]. Long-term studies are needed to better understand the efficacy and safety profile of fostamatinib in patients with chronic ITP.

\subsubsection{Splenectomy}

Spleen is the main site of the autoantibody production and platelet destruction. Splenectomy is long regarded as the gold standard therapy for ITP patients who are unresponsive to corticosteroids [144]. Compared to other treatment options, splenectomy has a higher sustainable response rate [4]. However, with the introduction of new medicaments, splenectomy has lost its place in the treatment of ITP $[75,145]$.

Splenectomy achieves a high rate of durable remissions in 60 to $70 \%$ of the patients [146]. The need for the third-line treatment is significantly lower in patients who have undergone splenectomy (20\%) compared to patients treated with second-line therapy (39-44\%) [147]. Vianelli et al. reported a relapse free survival in $67 \%$ of the patients for up to 20 years after splenectomy [148]. However, due to the surgical risks and potential longterm complications, splenectomy is usually reserved to chronic ITP patients who failed to respond to standard medical therapies or when therapies are contraindicated [50,144].

Furthermore, the lack of reliable predictors of response to splenectomy hinders the selection of the patients who will benefit from splenectomy [146]. Revealing the main site of platelet sequestration can help to predict the success of splenectomy. Autologous platelet scanning can be used to detect the site of platelet sequestration, but it is technically challenging and not widely available [149]. Knowledge of desialylation capacity of the anti-platelet autoantibodies might also be helpful to detect Fc-independent clearance of platelets in the liver [22].

Complications associated with splenectomy are post-operative bleeding, infection with encapsulated bacteria, sepsis as well as thromboembolic events in venous and arterial circulation (i.e., coronary artery disease, stroke and chronic thromboembolic pulmonary hypertension) [144]. In a retrospective analysis of medical records, among second line treatments, splenectomy had the highest frequency of deep vein thrombosis and pulmonary embolism [147]. Compared to open surgery, laparoscopic splenectomy has a lower rate of postoperative mortality and morbidity and a shorter hospitalization [146,150]. Moreover, the immediate as well as the persistent risks of venous thromboembolism have been shown to be higher among patients with ITP who have undergone splenectomy as compared those who have not [151,152].

Patient's age must also be taken into consideration during the selection process for splenectomy. Maria et al. showed that patients age at the time of the surgery predicted the response in children [153]. Older children show a better outcome after splenectomy. Recently, Kwiatkowska et al. showed that age $\left(<41\right.$ years) together with $\left(\mathrm{BMI}<24.3 \mathrm{~kg} / \mathrm{m}^{2}\right)$ and preoperative platelet count $\left(\geq 97 \times 103 \mathrm{~mm}^{3}\right)$ are independent prognostic factors for ITP remission after splenectomy [154]. Geriatric patients are prone to surgical complications and an increased relapse has been reported in ITP patients over 60 years $[155,156]$. Therefore, splenectomy should be implemented as a last resort in elderly patients. Last but not the least; splenectomy should not be performed in the first 12 to 24 months after ITP diagnosis because of the chances of spontaneous remission or disease stabilization [11].

\subsection{New Drugs under Investigation}

Rozanolixizumab is anti-neonatal $\mathrm{Fc}$ receptor $(\mathrm{FcRn})$ antibody that reduces plasma IgG levels. In a recent phase 2 study, $>50 \%$ patients with persistent/chronic primary ITP achieved clinically relevant platelet responses $\left(\geq 50 \times 10^{9} / \mathrm{L}\right)$ by day 8 after a single injection of rozanolixizumab at a dose of 15 and $20 \mathrm{mg} / \mathrm{kg}$ [157]. Treatment related mild-to- 
moderate adverse events have been seen in 15 of 66 (21\%) patients, and no serious infections have been reported. A phase 3 study is currently recruiting participants (NCT04224688).

Bortezomib, a proteosom inhibitor, induces apoptosis of long-lived autoreactive plasmocytes and reduces secretion of anti-platelet antibodies. In murine models of ITP, bortezomib eliminated long-lived plasmocytes and alleviated thrombocytopenia [158]. Beckman et al. used bortezomib to treat a 63-year-old female patient who had severe thrombocytopenia and bleeding episodes despite the utilization of several treatments including splenectomy [159]. The patient received bortezomib injections in addition to other treatments, and platelet count increased rapidly after the initiation of bortezomib. The results of the ongoing clinical trials (NCT03443570, NCT04083014) will help us to better define, if any, the role of bortezomib in ITP.

Efgartigimod is an Fc fragment that blocks FcRn. In a recent study, patients with a platelet count $<30 \times 10^{9} / \mathrm{L}$ despite treatment received four weekly intravenous injections of either placebo or efgartigimod, at a dose of $5 \mathrm{mg} / \mathrm{kg}$ or $10 \mathrm{mg} / \mathrm{kg}$ [160]. Antiplatelet antibody levels reduced $40 \%$ or more in $8 / 12(66.7 \%)$ patients treated with efgartigimod at $5 \mathrm{mg} / \mathrm{kg}$ and in $7 / 10(70.0 \%)$ patients treated with efgartigimod at $10 \mathrm{mg} / \mathrm{kg}$. A platelet response $>50 \times 10^{9} / \mathrm{L}$ on 2 occasions has been achieved in $46.2 \%$ of the patients on efgartigimod as compared to $25 \%$ on placebo [160]. A Phase 3 Study investigating the safety and efficacy of efgartigimod at a dose of $10 \mathrm{mg} / \mathrm{kg}$ is ongoing (NCT04225156).

Decitabine is an inhibitor of DNA methylation and used in the treatment of myelodysplastic syndrome. Considering the possible role of DNA-methylation in the aetiology of ITP [161], decitabine seems to be a potential treatment option. Low dose decitabine promotes megakaryocyte maturation and platelet production in patients with myelodysplastic syndrome and ITP [162,163]. In a prospective open label study, Zhou et. al. showed that an overall response rate of $51 \%$ with a median initial response time of 28 days in ITP patients [164]. The sustained response rates at 6,12 and 18 months were $44.44 \%(20 / 45)$, $31.11 \%(14 / 45)$ and $20.0 \%(9 / 45)$, respectively [164].

\section{Conclusions}

In recent years, ITP guidelines have been updated in the context of improved understanding of the pathophysiology of ITP and evidence supporting newly introduced treatments. Despite recent developments, the expected increase in the success rate of treatments has not been achieved yet. A substantial number of patients either do not respond at all or respond only transiently to many treatment interventions. The use of different treatment regimens targeting different key points in the pathophysiology of the disease may increase the success rate. In addition, the development of patient-specific testing methods, which can predict treatment success, may assist in avoiding complications, wasted time and associated costs from unnecessary treatments.

The management of ITP during ongoing 2019 coronavirus disease (COVID-19) pandemic has emerged as an additional challenge for clinicians. COVID-19, caused by severe acute respiratory syndrome coronavirus 2 (SARS-CoV-2), is known to be associated with increased coagulopathy and thrombotic complications [165]. Current data are insufficient to make evidence-based recommendations related to the ITP management. Pavord et al. published a series of recommendations based on expert opinion on the management of ITP during the COVID-19 pandemic [166]. They drew attention to a possible further increased risk of thrombosis in patients with COVID-19 from ITP or its treatment (particularly with TPO-RA). Mahevas et al. reported in a case series that COVID-19-associated ITP can lead to profound thrombocytopenia and severe bleeding manifestations but has a favourable outcome in most cases [167]. More studies are needed to make evidence-based decisions on managing ITP during the pandemic.

Current guidelines state that patient preferences should be prioritized when choosing a treatment regimen. Important factors that determine patient preferences include treatment efficacy and the potential for complications. Efficacy and safety data from post-marketing studies of new treatments will be helpful in this regard. In addition, randomized controlled 
trials comparing existing treatments not only in terms of treatment response or safety but also in terms of their impact on the health-related quality of life of patients with ITP are needed.

Author Contributions: A.S. conducted the literature search, created the figures and wrote the sections on pathophysiology and diagnosis of ITP. G.U. conducted the literature search and wrote the sections on clinical manifestations and treatment of ITP. T.B. designed the original layout and edited the manuscript. All authors have read and agreed to the published version of the manuscript.

Funding: This work was supported by grants from the German Research Foundation, the Herzstiftung (BA5158/4), Günther Landbeck Foundation and German Red Cross to T.B.

Institutional Review Board Statement: Not applicable.

Informed Consent Statement: Not applicable.

Data Availability Statement: Not applicable.

Acknowledgments: We thank Karina Althaus for insightful suggestions.

Conflicts of Interest: The authors declare no conflict of interest.

\section{References}

1. Provan, D.; Stasi, R.; Newland, A.C.; Blanchette, V.S.; Bolton-Maggs, P.; Bussel, J.B.; Chong, B.H.; Cines, D.B.; Gernsheimer, T.B.; Godeau, B.; et al. International consensus report on the investigation and management of primary immune thrombocytopenia. Blood 2010, 115, 168-186. [CrossRef]

2. Neunert, C.; Lim, W.; Crowther, M.; Cohen, A.; Solberg, L.; Crowther, M.A. The American Society of Hematology 2011 evidencebased practice guideline for immune thrombocytopenia. Blood 2011, 117, 4190-4207. [CrossRef]

3. Moulis, G.; Palmaro, A.; Montastruc, J.-L.; Godeau, B.; Lapeyre-Mestre, M.; Sailler, L. Epidemiology of incident immune thrombocytopenia: a nationwide population-based study in France. Blood 2014, 124, 3308-3315. [CrossRef] [PubMed]

4. Neunert, C.; Terrell, D.R.; Arnold, D.M.; Buchanan, G.; Cines, D.B.; Cooper, N.; Cuker, A.; Despotovic, J.M.; George, J.N.; Grace, R.F.; et al. American Society of Hematology 2019 guidelines for immune thrombocytopenia. Blood Adv. 2019, 3, $3829-3866$. [CrossRef]

5. McKenzie, C.G.J.; Guo, L.; Freedman, J.; Semple, J.W. Cellular immune dysfunction in immune thrombocytopenia (ITP). Br. J. Haematol. 2013, 163, 10-23. [CrossRef] [PubMed]

6. Shulman, N.R.; Marder, V.J.; Weinrach, R.S. Similarities between known antiplatelet antibodies and the factor responsible for thrombocytopenia in idiopathic purpura. Physiologic, serologic and isotopic studies. Ann. NY Acad. Sci. 1965, 124, 499-542. [CrossRef]

7. Ku, F.-C.; Tsai, C.-R.; Der Wang, J.; Wang, C.H.; Chang, T.-K.; Hwang, W.-L. Stromal-derived factor-1 gene variations in pediatric patients with primary immune thrombocytopenia. Eur. J. Haematol. 2013, 90, 25-30. [CrossRef] [PubMed]

8. Rank, A.; Weigert, O.; Ostermann, H. Management of chronic immune thrombocytopenic purpura: targeting insufficient megakaryopoiesis as a novel therapeutic principle. Biologics 2010, 4, 139-145. [CrossRef] [PubMed]

9. Cines, D.B.; Liebman, H.A. The Immune Thrombocytopenia Syndrome: A Disorder of Diverse Pathogenesis and Clinical Presentation. Hematol. Oncol. Clin. North Am. 2009, 23, 1155-1161. [CrossRef] [PubMed]

10. D'Orazio, J.A.; Neely, J.; Farhoudi, N. ITP in Children. J. Pediatric Hematol. Oncol. 2013, 35, 1-13. [CrossRef] [PubMed]

11. Provan, D.; Arnold, D.M.; Bussel, J.B.; Chong, B.H.; Cooper, N.; Gernsheimer, T.; Ghanima, W.; Godeau, B.; González-López, T.J.; Grainger, J.; et al. Updated international consensus report on the investigation and management of primary immune thrombocytopenia. Blood Adv. 2019, 3, 3780-3817. [CrossRef] [PubMed]

12. Bakchoul, T.; Sachs, U.J. Platelet destruction in immune thrombocytopenia. Understanding the mechanisms. Hamostaseologie 2016, 36, 187-194. [CrossRef]

13. Zhao, Z.; Yang, L.; Yang, G.; Zhuang, Y.; Qian, X.; Zhou, X.; Xiao, D.; Shen, Y. Contributions of T Lymphocyte Abnormalities to Therapeutic Outcomes in Newly Diagnosed Patients with Immune Thrombocytopenia. PLoS ONE 2015, 10, e0126601. [CrossRef] [PubMed]

14. Ji, X.; Zhang, L.; Peng, J.; Hou, M. T cell immune abnormalities in immune thrombocytopenia. J. Hematol. Oncol. 2014, 7. [CrossRef] [PubMed]

15. Zhang, F.; Chu, X.; Wang, L.; Zhu, Y.; Li, L.; Ma, D.; Peng, J.; Hou, M. Cell-mediated lysis of autologous platelets in chronic idiopathic thrombocytopenic purpura. Eur. J. Haematol. 2006, 76, 427-431. [CrossRef] [PubMed]

16. Zhao, C.; Li, X.; Zhang, F.; Wang, L.; Peng, J.; Hou, M. Increased cytotoxic T-lymphocyte-mediated cytotoxicity predominant in patients with idiopathic thrombocytopenic purpura without platelet autoantibodies. Haematologica 2008, 93, 1428-1430. [CrossRef]

17. Bakchoul, T.; Walek, K.; Krautwurst, A.; Rummel, M.; Bein, G.; Santoso, S.; Sachs, U.J. Glycosylation of autoantibodies: insights into the mechanisms of immune thrombocytopenia. Thromb. Haemost. 2013, 110, 1259-1266. [CrossRef] 
18. Kashiwagi, H.; Tomiyama, Y. Pathophysiology and management of primary immune thrombocytopenia. Int. J. Hematol. 2013, 98, 24-33. [CrossRef]

19. Nieswandt, B.; Bergmeier, W.; Rackebrandt, K.; Gessner, J.E.; Zirngibl, H. Identification of critical antigen-specific mechanisms in the development of immune thrombocytopenic purpura in mice. Blood 2000, 96, 2520-2527. [CrossRef]

20. Nieswandt, B.; Bergmeier, W.; Schulte, V.; Rackebrandt, K.; Gessner, J.E.; Zirngibl, H. Expression and function of the mouse collagen receptor glycoprotein VI is strictly dependent on its association with the FcRgamma chain. J. Biol. Chem. 2000, 275, 23998-24002. [CrossRef] [PubMed]

21. Webster, M.L.; Sayeh, E.; Crow, M.; Chen, P.; Nieswandt, B.; Freedman, J.; Ni, H. Relative efficacy of intravenous immunoglobulin $\mathrm{G}$ in ameliorating thrombocytopenia induced by antiplatelet GPIIbIIIa versus GPIbalpha antibodies. Blood 2006, 108, 943-946. [CrossRef] [PubMed]

22. Li, J.; van der Wal, D.E.; Zhu, G.; Xu, M.; Yougbare, I.; Ma, L.; Vadasz, B.; Carrim, N.; Grozovsky, R.; Ruan, M.; et al. Desialylation is a mechanism of Fc-independent platelet clearance and a therapeutic target in immune thrombocytopenia. Nat. Commun. 2015, 6. [CrossRef] [PubMed]

23. Qiu, J.; Liu, X.; Li, X.; Zhang, X.; Han, P.; Zhou, H.; Shao, L.; Hou, Y.; Min, Y.; Kong, Z.; et al. CD8(+) T cells induce platelet clearance in the liver via platelet desialylation in immune thrombocytopenia. Sci. Rep. 2016, 6, 27445. [CrossRef] [PubMed]

24. Tao, L.; Zeng, Q.; Li, J.; Xu, M.; Wang, J.; Pan, Y.; Wang, H.; Tao, Q.; Chen, Y.; Peng, J.; et al. Platelet desialylation correlates with efficacy of first-line therapies for immune thrombocytopenia. J. Hematol. Oncol. 2017, 10. [CrossRef] [PubMed]

25. Quach, M.E.; Dragovich, M.A.; Chen, W.; Syed, A.K.; Cao, W.; Liang, X.; Deng, W.; de Meyer, S.F.; Zhu, G.; Peng, J.; et al. Fc-independent immune thrombocytopenia via mechanomolecular signaling in platelets. Blood 2018, 131, 787-796. [CrossRef]

26. Marini, I.; Zlamal, J.; Faul, C.; Holzer, U.; Hammer, S.; Pelzl, L.; Bethge, W.; Althaus, K.; Bakchoul, T. Autoantibody-mediated desialylation impairs human thrombopoiesis and platelet lifespan. Haematologica 2020, 106, 196-207. [CrossRef]

27. Mason, K.D.; Carpinelli, M.R.; Fletcher, J.I.; Collinge, J.E.; Hilton, A.A.; Ellis, S.; Kelly, P.N.; Ekert, P.G.; Metcalf, D.; Roberts, A.W.; et al. Programmed Anuclear Cell Death Delimits Platelet Life Span. Cell 2007, 128, 1173-1186. [CrossRef]

28. Van der Wal, D.E.; Gitz, E.; Du, V.X.; Lo, K.S.L.; Koekman, C.A.; Versteeg, S.; Akkerman, J.W.N. Arachidonic acid depletion extends survival of cold-stored platelets by interfering with the glycoprotein Ib $\alpha-14-3-3 \zeta$ association. Haematologica 2012, 97, 1514-1522. [CrossRef]

29. Álvarez Román, M.; Bello, I.; Arias-Salgado, E.G.; Pollmar, M.I.; Yuste, V.; Salces, M.; Butta, N.V. Effects of thrombopoietin receptor agonists on procoagulant state in patients with immune thrombocytopenia. Thromb. Haemost. 2014, 112, 65-72. [CrossRef]

30. Winkler, J.; Kroiss, S.; Rand, M.L.; Azzouzi, I.; Annie Bang, K.W.; Speer, O.; Schmugge, M. Platelet apoptosis in paediatric immune thrombocytopenia is ameliorated by intravenous immunoglobulin. Br. J. Haematol. 2012, 156, 508-515. [CrossRef]

31. Goette, N.P.; Glembotsky, A.C.; Lev, P.R.; Grodzielski, M.; Contrufo, G.; Pierdominici, M.S.; Espasandin, Y.R.; Riveros, D.; García, A.J.; Molinas, F.C.; et al. Platelet Apoptosis in Adult Immune Thrombocytopenia: Insights into the Mechanism of Damage Triggered by Auto-Antibodies. PLoS ONE 2016, 11, e0160563. [CrossRef]

32. Marini, I.; Bakchoul, T. Pathophysiology of Autoimmune Thrombocytopenia: Current Insight with a Focus on Thrombopoiesis. Hamostaseologie 2019, 39, 227-237. [CrossRef]

33. McMillan, R.; Luiken, G.A.; Levy, R.; Yelenosky, R.; Longmire, R.L. Antibody against megakaryocytes in idiopathic thrombocytopenic purpura. JAMA 1978, 239, 2460-2462. [CrossRef]

34. Takahashi, R.; Sekine, N.; Nakatake, T. Influence of monoclonal antiplatelet glycoprotein antibodies on in vitro human megakaryocyte colony formation and proplatelet formation. Blood 1999, 93, 1951-1958. [CrossRef]

35. Chang, M.; Nakagawa, P.A.; Williams, S.A.; Schwartz, M.R.; Imfeld, K.L.; Buzby, J.S.; Nugent, D.J. Immune thrombocytopenic purpura (ITP) plasma and purified ITP monoclonal autoantibodies inhibit megakaryocytopoiesis in vitro. Blood 2003, 102, 887-895 [CrossRef]

36. McMillan, R.; Wang, L.; Tomer, A.; Nichol, J.; Pistillo, J. Suppression of in vitro megakaryocyte production by antiplatelet autoantibodies from adult patients with chronic ITP. Blood 2004, 103, 1364-1369. [CrossRef]

37. Iraqi, M.; Perdomo, J.; Yan, F.; Choi, P.Y.-I.; Chong, B.H. Immune thrombocytopenia: antiplatelet autoantibodies inhibit proplatelet formation by megakaryocytes and impair platelet production in vitro. Haematologica 2015, 100, 623-632. [CrossRef]

38. Yang, L.; Wang, L.; Zhao, C.; Zhu, X.; Hou, Y.; Jun, P.; Hou, M. Contributions of TRAIL-mediated megakaryocyte apoptosis to impaired megakaryocyte and platelet production in immune thrombocytopenia. Blood 2010, 116, 4307-4316. [CrossRef] [PubMed]

39. Radley, J.M.; Haller, C.J. Fate of senescent megakaryocytes in the bone marrow. Br. J. Haematol. 1983, 53, 277-287. [CrossRef] [PubMed]

40. Houwerzijl, E.J.; Blom, N.R.; van der Want, J.J.L.; Esselink, M.T.; Koornstra, J.J.; Smit, J.W.; Louwes, H.; Vellenga, E.; de Wolf, J.T.M. Ultrastructural study shows morphologic features of apoptosis and para-apoptosis in megakaryocytes from patients with idiopathic thrombocytopenic purpura. Blood 2004, 103, 500-506. [CrossRef] [PubMed]

41. Vrbensky, J.R.; Nazy, I.; Toltl, L.J.; Ross, C.; Ivetic, N.; Smith, J.W.; Kelton, J.G.; Arnold, D.M. Megakaryocyte apoptosis in immune thrombocytopenia. Platelets 2018, 29, 729-732. [CrossRef] [PubMed]

42. Neylon, A.J.; Saunders, P.W.G.; Howard, M.R.; Proctor, S.J.; Taylor, P.R.A. Clinically significant newly presenting autoimmune thrombocytopenic purpura in adults: A prospective study of a population-based cohort of 245 patients. Br. J. Haematol. 2003, 122, 966-974. [CrossRef] 
43. Lee, J.Y.; Lee, J.-H.; Lee, H.; Kang, B.; Kim, J.-W.; Kim, S.H.; Lee, J.-O.; Kim, J.W.; Kim, Y.J.; Lee, K.-W.; et al. Epidemiology and management of primary immune thrombocytopenia: A nationwide population-based study in Korea. Thromb. Res. 2017, 155, 86-91. [CrossRef]

44. Schoonen, W.M.; Kucera, G.; Coalson, J.; Li, L.; Rutstein, M.; Mowat, F.; Fryzek, J.; Kaye, J.A. Epidemiology of immune thrombocytopenic purpura in the General Practice Research Database. Br. J. Haematol. 2009, 145, 235-244. [CrossRef]

45. Grimaldi-Bensouda, L.; Nordon, C.; Michel, M.; Viallard, J.-F.; Adoue, D.; Magy-Bertrand, N.; Durand, J.-M.; Quittet, P.; Fain, O.; Bonnotte, B.; et al. Immune thrombocytopenia in adults: A prospective cohort study of clinical features and predictors of outcome. Haematologica 2016, 101, 1039-1045. [CrossRef]

46. Sailer, T.; Lechner, K.; Panzer, S.; Kyrle, P.A.; Pabinger, I. The course of severe autoimmune thrombocytopenia in patients not undergoing splenectomy. Haematologica 2006, 91, 1041-1045. [CrossRef]

47. Kühne, T.; Buchanan, G.R.; Zimmerman, S.; Michaels, L.A.; Kohan, R.; Berchtold, W.; Imbach, P. A prospective comparative study of 2540 infants and children with newly diagnosed idiopathic thrombocytopenic purpura (ITP) from the Intercontinental Childhood ITP Study Group. J. Pediatrics 2003, 143, 605-608. [CrossRef]

48. Imbach, P.; Kühne, T.; Müller, D.; Berchtold, W.; Zimmerman, S.; Elalfy, M.; Buchanan, G.R. Childhood ITP: 12 months follow-up data from the prospective registry I of the Intercontinental Childhood ITP Study Group (ICIS). Pediatr. Blood Cancer 2006, 46, 351-356. [CrossRef]

49. Jaime-Pérez, J.C.; Aguilar-Calderón, P.; Jiménez-Castillo, R.A.; Ramos-Dávila, E.M.; Salazar-Cavazos, L.; Gómez-Almaguer, D. Treatment outcomes and chronicity predictors for primary immune thrombocytopenia: 10-year data from an academic center. Ann. Hematol. 2020, 99, 2513-2520. [CrossRef] [PubMed]

50. Matzdorff, A.; Meyer, O.; Ostermann, H.; Kiefel, V.; Eberl, W.; Kühne, T.; Pabinger, I.; Rummel, M. Immune ThrombocytopeniaCurrent Diagnostics and Therapy: Recommendations of a Joint Working Group of DGHO, ÖGHO, SGH, GPOH, and DGTI Oncol. Res. Treat. 2018, 41 (Suppl. 5), 1-30. [CrossRef] [PubMed]

51. Adelborg, K.; Kristensen, N.R.; Nørgaard, M.; Bahmanyar, S.; Ghanima, W.; Kilpatrick, K.; Frederiksen, H.; Ekstrand, C.; Sørensen, H.T.; Fynbo Christiansen, C. Cardiovascular and bleeding outcomes in a population-based cohort of patients with chronic immune thrombocytopenia. J. Thromb. Haemost. 2019, 17, 912-924. [CrossRef] [PubMed]

52. Mithoowani, S.; Cervi, A.; Shah, N.; Ejaz, R.; Sirotich, E.; Barty, R.; Li, N.; Nazy, I.; Arnold, D.M. Management of major bleeds in patients with immune thrombocytopenia. J. Thromb. Haemost. 2020, 18, 1783-1790. [CrossRef]

53. Cohen, Y.C.; Djulbegovic, B.; Shamai-Lubovitz, O.; Mozes, B. The bleeding risk and natural history of idiopathic thrombocytopenic purpura in patients with persistent low platelet counts. Arch. Intern. Med. 2000, 160, 1630-1638. [CrossRef] [PubMed]

54. Neunert, C.; Noroozi, N.; Norman, G.; Buchanan, G.R.; Goy, J.; Nazi, I.; Kelton, J.G.; Arnold, D.M. Severe bleeding events in adults and children with primary immune thrombocytopenia: a systematic review. J. Thromb. Haemost. 2015, 13, 457-464. [CrossRef]

55. Forsythe, A.; Schneider, J.; Pham, T.; Bhor, M.; Said, Q.; Allepuz, A.; Socorro O Portella, M.D.; Kwon, C.S.; Roy, A.N. Real-world evidence on clinical outcomes in immune thrombocytopenia treated with thrombopoietin receptor agonists. J. Comp. Eff. Res. 2020, 9, 447-457. [CrossRef]

56. Arnold, D.M.; Nazy, I.; Clare, R.; Jaffer, A.M.; Aubie, B.; Li, N.; Kelton, J.G. Misdiagnosis of primary immune thrombocytopenia and frequency of bleeding: Lessons from the McMaster ITP Registry. Blood Adv. 2017, 1, 2414-2420. [CrossRef]

57. Piel-Julian, M.-L.; Mahévas, M.; Germain, J.; Languille, L.; Comont, T.; Lapeyre-Mestre, M.; Payrastre, B.; Beyne-Rauzy, O.; Michel, M.; Godeau, B.; et al. Risk factors for bleeding, including platelet count threshold, in newly diagnosed immune thrombocytopenia adults. J. Thromb. Haemost. 2018, 16, 1830-1842. [CrossRef]

58. Hato, T.; Shimada, N.; Kurata, Y.; Kuwana, M.; Fujimura, K.; Kashiwagi, H.; Takafuta, T.; Murata, M.; Tomiyama, Y. Risk factors for skin, mucosal, and organ bleeding in adults with primary ITP: A nationwide study in Japan. Blood Adv. 2020, 4, 1648-1655. [CrossRef] [PubMed]

59. Newton, J.L.; Reese, J.A.; Watson, S.I.; Vesely, S.K.; Bolton-Maggs, P.H.B.; George, J.N.; Terrell, D.R. Fatigue in adult patients with primary immune thrombocytopenia. Eur. J. Haematol. 2011, 86, 420-429. [CrossRef]

60. Kuter, D.J.; Mathias, S.D.; Rummel, M.; Mandanas, R.; Giagounidis, A.A.; Wang, X.; Deuson, R.R. Health-related quality of life in nonsplenectomized immune thrombocytopenia patients receiving romiplostim or medical standard of care. Am. J. Hematol. 2012, 87, 558-561. [CrossRef]

61. Blatt, J.; Weston, B.; Gold, S. Fatigue as marker of thrombocytopenia in childhood idiopathic thrombocytopenic purpura. Pediatr. Hematol. Oncol. 2010, 27, 65-67. [CrossRef]

62. Hill, Q.A.; Newland, A.C. Fatigue in immune thrombocytopenia. Br. J. Haematol. 2015, 170, 141-149. [CrossRef] [PubMed]

63. Severinsen, M.T.; Engebjerg, M.C.; Farkas, D.K.; Jensen, A.Ø.; Nørgaard, M.; Zhao, S.; Sørensen, H.T. Risk of venous thromboembolism in patients with primary chronic immune thrombocytopenia: A Danish population-based cohort study. Br. J. Haematol. 2011, 152, 360-362. [CrossRef] [PubMed]

64. Doobaree, I.U.; Nandigam, R.; Bennett, D.; Newland, A.; Provan, D. Thromboembolism in adults with primary immune thrombocytopenia: A systematic literature review and meta-analysis. Eur. J. Haematol. 2016, 97, 321-330. [CrossRef]

65. Hollenhorst, M.A.; Al-Samkari, H.; Kuter, D.J. Markers of autoimmunity in immune thrombocytopenia: Prevalence and prognostic significance. Blood Adv. 2019, 3, 3515-3521. [CrossRef] [PubMed]

66. Peerschke, E.I.; Yin, W.; Ghebrehiwet, B. Complement activation on platelets: Implications for vascular inflammation and thrombosis. Mol. Immunol. 2010, 47, 2170-2175. [CrossRef] [PubMed] 
67. Kuter, D.J.; Bussel, J.B.; Newland, A.; Baker, R.I.; Lyons, R.M.; Wasser, J.; Viallard, J.-F.; Macik, G.; Rummel, M.; Nie, K.; et al. Long-term treatment with romiplostim in patients with chronic immune thrombocytopenia: Safety and efficacy. Br. J. Haematol. 2013, 161, 411-423. [CrossRef]

68. Rodeghiero, F.; Stasi, R.; Giagounidis, A.; Viallard, J.-F.; Godeau, B.; Pabinger, I.; Cines, D.; Liebman, H.; Wang, X.; Woodard, P. Long-term safety and tolerability of romiplostim in patients with primary immune thrombocytopenia: A pooled analysis of 13 clinical trials. Eur. J. Haematol. 2013, 91, 423-436. [CrossRef]

69. Frederiksen, H.; Maegbaek, M.L.; Nørgaard, M. Twenty-year mortality of adult patients with primary immune thrombocytopenia: A Danish population-based cohort study. Br. J. Haematol. 2014, 166, 260-267. [CrossRef]

70. Vollenberg, R.; Jouni, R.; Norris, P.A.A.; Burg-Roderfeld, M.; Cooper, N.; Rummel, M.J.; Bein, G.; Marini, I.; Bayat, B.; Burack, R.; et al. Glycoprotein V is a relevant immune target in patients with immune thrombocytopenia. Haematologica 2019, 104, 1237-1243. [CrossRef] [PubMed]

71. Kiefel, V.; Freitag, E.; Kroll, H.; Santoso, S.; Mueller-Eckhardt, C. Platelet autoantibodies (IgG, IgM, IgA) against glycoproteins $\mathrm{IIb} / \mathrm{IIIa}$ and $\mathrm{Ib} / \mathrm{IX}$ in patients with thrombocytopenia. Ann. Hematol. 1996, 72, 280-285. [CrossRef] [PubMed]

72. Newland, A.; Lee, E.-J.; McDonald, V.; Bussel, J.B. Fostamatinib for persistent/chronic adult immune thrombocytopenia. Immunotherapy 2018, 10, 9-25. [CrossRef]

73. Page, L.K.; Psaila, B.; Provan, D.; Michael Hamilton, J.; Jenkins, J.M.; Elish, A.S.; Lesser, M.L.; Bussel, J.B. The immune thrombocytopenic purpura (ITP) bleeding score: Assessment of bleeding in patients with ITP. Br. J. Haematol. 2007, 138, 245-248. [CrossRef]

74. Palau, J.; Jarque, I.; Sanz, M.A. Long-term management of chronic immune thrombocytopenic purpura in adults. Int. J. Gen. Med. 2010, 3, 305-311. [CrossRef]

75. McGrath, L.J.; Kilpatrick, K.; Overman, R.A.; Reams, D.; Sharma, A.; Altomare, I.; Wasser, J.; Brookhart, M.A. Treatment Patterns Among Adults with Primary Immune Thrombocytopenia Diagnosed in Hematology Clinics in the United States. Clin. Epidemiol. 2020, 12, 435-445. [CrossRef]

76. Branehög, I.; Weinfeld, A. Platelet survival and platelet production in idiopathic thrombocytopenic purpura (ITP) before and during treatment with corticosteroids. Scand. J. Haematol. 1974, 12, 69-79. [CrossRef] [PubMed]

77. Gernsheimer, T.; Stratton, J.; Ballem, P.J.; Slichter, S.J. Mechanisms of response to treatment in autoimmune thrombocytopenic purpura. N. Engl. J. Med. 1989, 320, 974-980. [CrossRef]

78. Wang, L.; Xu, L.; Hao, H.; Jansen, A.J.G.; Liu, G.; Li, H.; Liu, X.; Zhao, Y.; Peng, J.; Hou, M. First line treatment of adult patients with primary immune thrombocytopenia: A real-world study. Platelets 2020, 31, 55-61. [CrossRef]

79. Mithoowani, S.; Gregory-Miller, K.; Goy, J.; Miller, M.C.; Wang, G.; Noroozi, N.; Kelton, J.G.; Arnold, D.M. High-dose dexamethasone compared with prednisone for previously untreated primary immune thrombocytopenia: A systematic review and meta-analysis. Lancet Haematol. 2016, 3, e489-e496. [CrossRef]

80. Ma, J.; Fu, L.; Chen, Z.; Gu, H.; Ma, J.; Wu, R. High-dose dexamethasone as a replacement for traditional prednisone as the first-line treatment in children with previously untreated primary immune thrombocytopenia: A prospective, randomized single-center study. Int. J. Hematol. 2020, 112, 773-779. [CrossRef] [PubMed]

81. Frederiksen, H.; Ghanima, W. Response of first line treatment with corticosteroids in a population-based cohort of adults with primary immune thrombocytopenia. Eur. J. Intern. Med. 2017, 37, e23-e25. [CrossRef] [PubMed]

82. Cheng, Y.; Wong, R.S.; Soo, Y.O.; Chui, C.H.; Lau, F.Y.; Chan, N.P.; Wong, W.S.; Cheng, G. Initial Treatment of Immune Thrombocytopenic Purpura with High-Dose Dexamethasone. N. Engl. J. Med. 2003, 349, 831-836. [CrossRef]

83. Wang, J.; Li, Y.; Wang, C.; Zhang, Y.; Gao, C.; Lang, H.; Chen, X. Efficacy and Safety of the Combination Treatment of Rituximab and Dexamethasone for Adults with Primary Immune Thrombocytopenia (ITP): A Meta-Analysis. Biomed Res. Int. 2018, 2018, 1316096. [CrossRef] [PubMed]

84. Imbach, P. Treatment of immune thrombocytopenia with intravenous immunoglobulin and insights for other diseases. A historical review. Swiss Med. Wkly. 2012, 142, w13593. [CrossRef]

85. Lazarus, A.H.; Crow, A.R. Mechanism of action of IVIG and anti-D in ITP. Transfus. Apher. Sci. 2003, 28, 249-255. [CrossRef]

86. Beck, C.E.; Nathan, P.C.; Parkin, P.C.; Blanchette, V.S.; Macarthur, C. Corticosteroids Versus Intravenous Immune Globulin for the Treatment of Acute Immune Thrombocytopenic Purpura in Children: A Systematic Review and Meta-Analysis of Randomized Controlled Trials. J. Pediatrics 2005, 147, 521-527. [CrossRef]

87. Zhou, Z.; Qiao, Z.; Li, H.; Luo, N.; Zhang, X.; Xue, F.; Yang, R. Different dosages of intravenous immunoglobulin (IVIg) in treating immune thrombocytopenia with long-term follow-up of three years: Results of a prospective study including 167 cases. Autoimmunity 2016, 49, 50-57. [CrossRef] [PubMed]

88. Qin, Y.-H.; Zhou, T.-B.; Su, L.-N.; Lei, F.-Y.; Zhao, Y.-J.; Huang, W.-F. The efficacy of different dose intravenous immunoglobulin in treating acute idiopathic thrombocytopenic purpura: a meta-analysis of 13 randomized controlled trials. Blood Coagul. Fibrinolysis 2010, 21, 713-721. [CrossRef]

89. Jacobs, P.; Wood, L.; Novitzky, N. Intravenous gammaglobulin has no advantages over oral corticosteroids as primary therapy for adults with immune thrombocytopenia: A prospective randomized clinical trial. Am. J. Med. 1994, 97, 55-59. [CrossRef]

90. Godeau, B.; Chevret, S.; Varet, B.; Lefrère, F.; Zini, J.-M.; Bassompierre, F.; Chèze, S.; Legouffe, E.; Hulin, C.; Grange, M.-J.; et al. Intravenous immunoglobulin or high-dose methylprednisolone, with or without oral prednisone, for adults with untreated severe autoimmune thrombocytopenic purpura: A randomised, multicentre trial. Lancet 2002, 359, 23-29. [CrossRef] 
91. Peng, J.; Ma, S.-H.; Liu, J.; Hou, Y.; Liu, X.-M.; Niu, T.; Xu, R.-R.; Guo, C.-S.; Wang, X.-M.; Cheng, Y.-F.; et al. Association of autoantibody specificity and response to intravenous immunoglobulin $\mathrm{G}$ therapy in immune thrombocytopenia: A multicenter cohort study. J. Thromb. Haemost. 2014, 12, 497-504. [CrossRef]

92. Al-Samkari, H.; Rosovsky, R.P.; Karp Leaf, R.S.; Smith, D.B.; Goodarzi, K.; Fogerty, A.E.; Sykes, D.B.; Kuter, D.J. A modern reassessment of glycoprotein-specific direct platelet autoantibody testing in immune thrombocytopenia. Blood Adv. 2020, 4, 9-18. [CrossRef]

93. Dash, C.H.; Gillanders, K.R.; Stratford Bobbitt, M.E.; Gascoigne, E.W.; Leach, S.J. Safety and efficacy of Gammaplex ${ }^{\circledR}$ in idiopathic thrombocytopenic purpura (ClinicalTrials.gov-NCT00504075). PLoS ONE 2014, 9, e96600. [CrossRef] [PubMed]

94. Bonilla, F.A. Intravenous immunoglobulin: Adverse reactions and management. J. Allergy Clin. Immunol. 2008, 122, 1238-1239. [CrossRef] [PubMed]

95. Bussel, J.B.; Graziano, J.N.; Kimberly, R.P.; Pahwa, S.; Aledort, L.M. Intravenous anti-D treatment of immune thrombocytopenic purpura: Analysis of efficacy, toxicity, and mechanism of effect. Blood 1991, 77, 1884-1893. [CrossRef]

96. Cheung, E.; Liebman, H.A. Anti-RhD immunoglobulin in the treatment of immune thrombocytopenia. Biologics 2009, 3, 57-62. [PubMed]

97. Meyer, O.; Kiesewetter, H.; Hermsen, M.; Petriedes, P.; Rose, M.; Seibt, H.; Salama, A. Replacement of intravenous administration of anti-D by subcutaneous administration in patients with autoimmune thrombocytopenia. Pediatr. Blood Cancer 2006, 47, 721-722. [CrossRef] [PubMed]

98. Scaradavou, A.; Woo, B.; Woloski, B.M.; Cunningham-Rundles, S.; Ettinger, L.J.; Aledort, L.M.; Bussel, J.B. Intravenous anti-D treatment of immune thrombocytopenic purpura: Experience in 272 patients. Blood 1997, 89, 2689-2700. [CrossRef]

99. Gaines, A.R. Disseminated intravascular coagulation associated with acute hemoglobinemia or hemoglobinuria following $\mathrm{Rh}(0)(\mathrm{D})$ immune globulin intravenous administration for immune thrombocytopenic purpura. Blood 2005, 106, 1532-1537. [CrossRef]

100. Tarantino, M.D.; Bussel, J.B.; Cines, D.B.; McCrae, K.R.; Gernsheimer, T.; Liebman, H.A.; Wong, W.-Y.; Kulkarni, R.; Grabowski, E.; McMillan, R. A closer look at intravascular hemolysis (IVH) following intravenous anti-D for immune thrombocytopenic purpura (ITP). Blood 2007, 109, 5527. [CrossRef]

101. Roumier, M.; Le Burel, S.; Audia, S.; Chauchet, A.; Gousseff, M.; Hamidou, M.; Liferman, F.; Moulis, G.; Lioger, B.; Galicier, L.; et al. High dose romiplostim as a rescue therapy for adults with severe bleeding and refractory immune thrombocytopenia. Am. J. Hematol. 2020. [CrossRef]

102. Mayer, B.; Salama, A. Successful treatment of bleeding with tranexamic acid in a series of 12 patients with immune thrombocytopenia. Vox Sang. 2017, 112, 767-772. [CrossRef] [PubMed]

103. Bartholomew, J.R.; Salgia, R.; Bell, W.R. Control of bleeding in patients with immune and nonimmune thrombocytopenia with aminocaproic acid. Arch. Intern. Med. 1989, 149, 1959-1961. [CrossRef] [PubMed]

104. Randall, M.M.; Nurse, J.; Singh, K.P. Tranexamic Acid in a Case Report of Life-threatening Nontraumatic Hemorrhage in Immune Thrombocytopenic Purpura. Clin. Pract. Cases Emerg. Med. 2020, 4, 421-423. [CrossRef]

105. Gurion, R.; Siu, A.; Weiss, A.R.; Masterson, M. Use of Recombinant Factor VIIa in a Pediatric Patient with Initial Presentation of Refractory Acute Immune Thrombocytopenic Purpura and Severe Bleeding. J. Pediatr. Pharmacol. Ther. 2012, 17, 274-280. [CrossRef]

106. Gerotziafas, G.T.; Zervas, C.; Gavrielidis, G.; Tokmaktsis, A.; Hatjiharissi, E.; Papaioannou, M.; Lazaridou, A.; Constantinou, N.; Samama, M.M.; Christakis, J. Effective hemostasis with rFVIIa treatment in two patients with severe thrombocytopenia and life-threatening hemorrhage. Am. J. Hematol. 2002, 69, 219-222. [CrossRef]

107. Waddington, D.P.; McAuley, F.T.; Hanley, J.P.; Summerfield, G.P. The use of recombinant factor viia in a jehovah's witness with auto-immune thrombocytopenia and post-splenectomy haemorrhage. Br. J. Haematol. 2002, 119, 286-288. [CrossRef]

108. Kuter, D.J.; Arnold, D.M.; Rodeghiero, F.; Janssens, A.; Selleslag, D.; Bird, R.; Newland, A.; Mayer, J.; Wang, K.; Olie, R. Safety and efficacy of self-administered romiplostim in patients with immune thrombocytopenia: Results of an integrated database of five clinical trials. Am. J. Hematol. 2020, 95, 643-651. [CrossRef]

109. Kuter, D.J.; Newland, A.; Chong, B.H.; Rodeghiero, F.; Romero, M.T.; Pabinger, I.; Chen, Y.; Wang, K.; Mehta, B.; Eisen, M. Romiplostim in adult patients with newly diagnosed or persistent immune thrombocytopenia (ITP) for up to 1 year and in those with chronic ITP for more than 1 year: A subgroup analysis of integrated data from completed romiplostim studies. Br. J. Haematol. 2019, 185, 503-513. [CrossRef] [PubMed]

110. Stasi, R.; Murali, M.; Michel, M.; Viallard, J.-F.; Giagounidis, A.; Janssens, A.; Legg, J.; Deuson, R.; Danese, M.D. Evaluation of bleeding-related episodes in patients with immune thrombocytopenia (ITP) receiving romiplostim or medical standard of care. Int. J. Hematol. 2012, 96, 26-33. [CrossRef]

111. Gernsheimer, T.B.; George, J.N.; Aledort, L.M.; Tarantino, M.D.; Sunkara, U.; Matthew Guo, D.; Nichol, J.L. Evaluation of bleeding and thrombotic events during long-term use of romiplostim in patients with chronic immune thrombocytopenia (ITP). J. Thromb. Haemost. 2010, 8, 1372-1382. [CrossRef]

112. Kuter, D.J.; Rummel, M.; Boccia, R.; Macik, B.G.; Pabinger, I.; Selleslag, D.; Rodeghiero, F.; Chong, B.H.; Wang, X.; Berger, D.P. Romiplostim or standard of care in patients with immune thrombocytopenia. N. Engl. J. Med. 2010, 363, 1889-1899. [CrossRef] 
113. Janssens, A.; Rodeghiero, F.; Anderson, D.; Chong, B.H.; Boda, Z.; Pabinger, I.; Červinek, L.; Terrell, D.R.; Wang, X.; Franklin, J. Changes in bone marrow morphology in adults receiving romiplostim for the treatment of thrombocytopenia associated with primary immune thrombocytopenia. Ann. Hematol. 2016, 95, 1077-1087. [CrossRef] [PubMed]

114. Lambert, M.P. TPO-mimetics and myelofibrosis? A reticulin question! Blood 2009, 114, 3722-3723. [CrossRef] [PubMed]

115. Kuter, D.J.; Mufti, G.J.; Bain, B.J.; Hasserjian, R.P.; Davis, W.; Rutstein, M. Evaluation of bone marrow reticulin formation in chronic immune thrombocytopenia patients treated with romiplostim. Blood 2009, 114, 3748-3756. [CrossRef] [PubMed]

116. Garnock-Jones, K.P. Spotlight on eltrombopag in treatment-refractory chronic primary immune thrombocytopenia. BioDrugs 2011, 25, 401-404. [CrossRef]

117. Al-Samkari, H.; Kuter, D.J. An alternative intermittent eltrombopag dosing protocol for the treatment of chronic immune thrombocytopenia. Br. J. Clin. Pharmacol. 2018, 84, 2673-2677. [CrossRef]

118. Promacta ${ }^{\circ}$ Prescription Information. Available online: www.accessdata.fda.gov/drugsatfda_docs/label/2015/207027s000lbl.pdf (accessed on 2 January 2021).

119. Bussel, J.B.; Provan, D.; Shamsi, T.; Cheng, G.; Psaila, B.; Kovaleva, L.; Salama, A.; Jenkins, J.M.; Roychowdhury, D.; Mayer, B.; et al. Effect of eltrombopag on platelet counts and bleeding during treatment of chronic idiopathic thrombocytopenic purpura: A randomised, double-blind, placebo-controlled trial. Lancet 2009, 373, 641-648. [CrossRef]

120. Tomiyama, Y.; Miyakawa, Y.; Okamoto, S.; Katsutani, S.; Kimura, A.; Okoshi, Y.; Ninomiya, H.; Kosugi, H.; Nomura, S.; Ozaki, K.; et al. A lower starting dose of eltrombopag is efficacious in Japanese patients with previously treated chronic immune thrombocytopenia. J. Thromb. Haemost. 2012, 10, 799-806. [CrossRef]

121. Yang, R.; Hou, M.; Li, J. Effect of eltrombopag on platelet response and safety results in Chinese adults with chronic ITP-primary result of a phase III study (abstract). Blood 2014, 124, 1464. [CrossRef]

122. Cheng, G.; Saleh, M.N.; Marcher, C.; Vasey, S.; Mayer, B.; Aivado, M.; Arning, M.; Stone, N.L.; Bussel, J.B. Eltrombopag for management of chronic immune thrombocytopenia (RAISE): A 6-month, randomised, phase 3 study. Lancet 2011, 377, 393-402. [CrossRef]

123. Wong, R.S.M.; Saleh, M.N.; Khelif, A.; Salama, A.; Portella, M.S.O.; Burgess, P.; Bussel, J.B. Safety and efficacy of long-term treatment of chronic/persistent ITP with eltrombopag: Final results of the EXTEND study. Blood 2017, 130, 2527-2536. [CrossRef] [PubMed]

124. González-López, T.J.; Pascual, C.; Álvarez-Román, M.T.; Fernández-Fuertes, F.; Sánchez-González, B.; Caparrós, I.; Jarque, I.; Mingot-Castellano, M.E.; Hernández-Rivas, J.A.; Martín-Salces, M.; et al. Successful discontinuation of eltrombopag after complete remission in patients with primary immune thrombocytopenia. Am. J. Hematol. 2015, 90, E40-E43. [CrossRef]

125. Al-Samkari, H.; Kuter, D.J. Thrombopoietin level predicts response to treatment with eltrombopag and romiplostim in immune thrombocytopenia. Am. J. Hematol. 2018, 93, 1501-1508. [CrossRef]

126. Mishra, K.; Pramanik, S.; Jandial, A.; Sahu, K.K.; Sandal, R.; Ahuja, A.; Yanamandra, U.; Kumar, R.; Kapoor, R.; Verma, T.; et al. Real-world experience of eltrombopag in immune thrombocytopenia. Am. J. Blood Res. 2020, 10, 240-251. [PubMed]

127. Doptelet@Prescribtion Information. Available online: www.accessdata.fda.gov/drugsatfda_docs/label/2018/210238s000lbl.pdf (accessed on 8 January 2021).

128. Jurczak, W.; Chojnowski, K.; Mayer, J.; Krawczyk, K.; Jamieson, B.D.; Tian, W.; Allen, L.F. Phase 3 randomised study of avatrombopag, a novel thrombopoietin receptor agonist for the treatment of chronic immune thrombocytopenia. Br. J. Haematol. 2018, 183, 479-490. [CrossRef] [PubMed]

129. Godeau, B. B-cell depletion in immune thrombocytopenia. Semin. Hematol. 2013, 50 (Suppl. 1), S75-S82. [CrossRef] [PubMed]

130. Chugh, S.; Darvish-Kazem, S.; Lim, W.; Crowther, M.A.; Ghanima, W.; Wang, G.; Heddle, N.M.; Kelton, J.G.; Arnold, D.M. Rituximab plus standard of care for treatment of primary immune thrombocytopenia: A systematic review and meta-analysis. Lancet Haematol. 2015, 2, e75-e81. [CrossRef]

131. Patel, V.L.; Mahévas, M.; Lee, S.Y.; Stasi, R.; Cunningham-Rundles, S.; Godeau, B.; Kanter, J.; Neufeld, E.; Taube, T.; Ramenghi, U.; et al. Outcomes 5 years after response to rituximab therapy in children and adults with immune thrombocytopenia. Blood 2012, 119, 5989-5995. [CrossRef]

132. Ghanima, W.; Khelif, A.; Waage, A.; Michel, M.; Tjønnfjord, G.E.; Romdhan, N.B.; Kahrs, J.; Darne, B.; Holme, P.A. Rituximab as second-line treatment for adult immune thrombocytopenia (the RITP trial): a multicentre, randomised, double-blind, placebocontrolled trial. Lancet 2015, 385, 1653-1661. [CrossRef]

133. Li, Y.; Shi, Y.; He, Z.; Chen, Q.; Liu, Z.; Yu, L.; Wang, C. The efficacy and safety of low-dose rituximab in immune thrombocytopenia: a systematic review and meta-analysis. Platelets 2019, 30, 690-697. [CrossRef]

134. Tjønnfjord, E.; Holme, P.A.; Darne, B.; Khelif, A.; Waage, A.; Michel, M.; Ben Romdhan, N.; Ghanima, W. Long-term outcomes of patients treated with rituximab as second-line treatment for adult immune thrombocytopenia - Follow-up of the RITP study. Br. J. Haematol. 2020, 191, 460-465. [CrossRef]

135. Hammond, W.A.; Vishnu, P.; Rodriguez, E.M.; Li, Z.; Dholaria, B.; Shreders, A.J.; Rivera, C.E. Sequence of Splenectomy and Rituximab for the Treatment of Steroid-Refractory Immune Thrombocytopenia: Does It Matter? Mayo Clin. Proc. 2019, 94, 2199-2208. [CrossRef]

136. Wang, Y.-M.; Yu, Y.-F.; Liu, Y.; Liu, S.; Hou, M.; Liu, X.-G. The association between antinuclear antibody and response to rituximab treatment in adult patients with primary immune thrombocytopenia. Hematology 2020, 25, 139-144. [CrossRef] [PubMed] 
137. Khellaf, M.; Charles-Nelson, A.; Fain, O.; Terriou, L.; Viallard, J.-F.; Cheze, S.; Graveleau, J.; Slama, B.; Audia, S.; Ebbo, M.; et al. Safety and efficacy of rituximab in adult immune thrombocytopenia: Results from a prospective registry including 248 patients. Blood 2014, 124, 3228-3236. [CrossRef] [PubMed]

138. Puavilai, T.; Thadanipon, K.; Rattanasiri, S.; Ingsathit, A.; McEvoy, M.; Attia, J.; Thakkinstian, A. Treatment efficacy for adult persistent immune thrombocytopenia: A systematic review and network meta-analysis. Br. J. Haematol. 2020, 188, 450-459. [CrossRef] [PubMed]

139. Podolanczuk, A.; Lazarus, A.H.; Crow, A.R.; Grossbard, E.; Bussel, J.B. Of mice and men: an open-label pilot study for treatment of immune thrombocytopenic purpura by an inhibitor of Syk. Blood 2009, 113, 3154-3160. [CrossRef] [PubMed]

140. Bussel, J.; Arnold, D.M.; Grossbard, E.; Mayer, J.; Treliński, J.; Homenda, W.; Hellmann, A.; Windyga, J.; Sivcheva, L.; Khalafallah, A.A.; et al. Fostamatinib for the treatment of adult persistent and chronic immune thrombocytopenia: Results of two phase 3 , randomized, placebo-controlled trials. Am. J. Hematol. 2018, 93, 921-930. [CrossRef]

141. Bussel, J.B.; Arnold, D.M.; Boxer, M.A.; Cooper, N.; Mayer, J.; Zayed, H.; Tong, S.; Duliege, A.-M. Long-term fostamatinib treatment of adults with immune thrombocytopenia during the phase 3 clinical trial program. Am. J. Hematol. 2019, 94, 546-553. [CrossRef]

142. Boccia, R.; Cooper, N.; Ghanima, W.; Boxer, M.A.; Hill, Q.A.; Sholzberg, M.; Tarantino, M.D.; Todd, L.K.; Tong, S.; Bussel, J.B. Fostamatinib is an effective second-line therapy in patients with immune thrombocytopenia. Br. J. Haematol. 2020, 190, 933-938. [CrossRef]

143. Tavalisse®Prescription Information. Available online: https://www.accessdata.fda.gov/drugsatfda_docs/label/2018/2092991bl. pdf (accessed on 2 January 2021).

144. Chaturvedi, S.; Arnold, D.M.; McCrae, K.R. Splenectomy for immune thrombocytopenia: Down but not out. Blood 2018, 131, 1172-1182. [CrossRef]

145. Palandri, F.; Polverelli, N.; Sollazzo, D.; Romano, M.; Catani, L.; Cavo, M.; Vianelli, N. Have splenectomy rate and main outcomes of ITP changed after the introduction of new treatments? A monocentric study in the outpatient setting during 35 years. Am. J. Hematol. 2016, 91, E267-E272. [CrossRef]

146. Kojouri, K.; Vesely, S.K.; Terrell, D.R.; George, J.N. Splenectomy for adult patients with idiopathic thrombocytopenic purpura: a systematic review to assess long-term platelet count responses, prediction of response, and surgical complications. Blood 2004, 104, 2623-2634. [CrossRef]

147. Lal, L.S.; Said, Q.; Andrade, K.; Cuker, A. Second-line treatments and outcomes for immune thrombocytopenia: A retrospective study with electronic health records. Res. Pract. Thromb. Haemost. 2020, 4, 1131-1140. [CrossRef] [PubMed]

148. Vianelli, N.; Palandri, F.; Polverelli, N.; Stasi, R.; Joelsson, J.; Johansson, E.; Ruggeri, M.; Zaja, F.; Cantoni, S.; Catucci, A.E.; et al. Splenectomy as a curative treatment for immune thrombocytopenia: A retrospective analysis of 233 patients with a minimum follow up of 10 years. Haematologica 2013, 98, 875-880. [CrossRef] [PubMed]

149. Amini, S.N.; Nelson, V.S.; Sobels, A.; Schoones, J.W.; Zwaginga, J.J.; Schipperus, M.R. Autologous platelet scintigraphy and clinical outcome of splenectomy in immune thrombocytopenia: A systematic review and meta-analysis. Crit. Rev. Oncol. Hematol. 2020, 153, 103040. [CrossRef] [PubMed]

150. Qu, Y.; Xu, J.; Jiao, C.; Cheng, Z.; Ren, S. Long-Term Outcomes of Laparoscopic Splenectomy Versus Open Splenectomy for Idiopathic Thrombocytopenic Purpura. Int. Surg. 2014, 99, 286-290. [CrossRef] [PubMed]

151. Nørgaard, M.; Cetin, K.; Maegbaek, M.L.; Kristensen, N.R.; Ghanima, W.; Bahmanyar, S.; Stryker, S.; Christiansen, C.F. Risk of arterial thrombotic and venous thromboembolic events in patients with primary chronic immune thrombocytopenia: A Scandinavian population-based cohort study. Br. J. Haematol. 2016, 174, 639-642. [CrossRef]

152. Boyle, S.; White, R.H.; Brunson, A.; Wun, T. Splenectomy and the incidence of venous thromboembolism and sepsis in patients with immune thrombocytopenia. Blood 2013, 121, 4782-4790. [CrossRef]

153. Maria, L.A.; Nour, A.; Eleanor, P.; Victor, B.; Paul, I.; Thomas, K.; Intercontinental, C.I.S.G. Long-term outcomes after splenectomy in children with immune thrombocytopenia: An update on the registry data from the Intercontinental Cooperative ITP Study Group. Haematologica 2019, 105, 2682-2685. [CrossRef]

154. Kwiatkowska, A.; Radkowiak, D.; Wysocki, M.; Torbicz, G.; Gajewska, N.; Lasek, A.; Kulawik, J.; Budzyński, A.; Pędziwiatr, M. Prognostic Factors for Immune Thrombocytopenic Purpura Remission after Laparoscopic Splenectomy: A Cohort Study. Medicina (Kaunas) 2019, 55. [CrossRef]

155. Gonzalez-Porras, J.R.; Escalante, F.; Pardal, E.; Sierra, M.; Garcia-Frade, L.J.; Redondo, S.; Arefi, M.; Aguilar, C.; Ortega, F.; de Cabo, E.; et al. Safety and efficacy of splenectomy in over 65-yrs-old patients with immune thrombocytopenia. Eur. J. Haematol. 2013, 91, 236-241. [CrossRef] [PubMed]

156. Park, Y.H.; Yi, H.G.; Kim, C.S.; Hong, J.; Park, J.; Lee, J.H.; Kim, H.Y.; Kim, H.J.; Zang, D.Y.; Kim, S.H.; et al. Clinical Outcome and Predictive Factors in the Response to Splenectomy in Elderly Patients with Primary Immune Thrombocytopenia: A Multicenter Retrospective Study. Acta Haematol. 2016, 135, 162-171. [CrossRef]

157. Robak, T.; Kaźmierczak, M.; Jarque, I.; Musteata, V.; Treliński, J.; Cooper, N.; Kiessling, P.; Massow, U.; Woltering, F.; Snipes, R.; et al. Phase 2 multiple-dose study of an FcRn inhibitor, rozanolixizumab, in patients with primary immune thrombocytopenia. Blood Adv. 2020, 4, 4136-4146. [CrossRef] 
158. Li, G.; Wang, S.; Li, N.; Liu, Y.; Feng, Q.; Zuo, X.; Li, X.; Hou, Y.; Shao, L.; Ma, C.; et al. Proteasome Inhibition with Bortezomib Induces Apoptosis of Long-Lived Plasma Cells in Steroid-Resistant or Relapsed Immune Thrombocytopaenia. Thromb. Haemost. 2018, 118, 1752-1764. [CrossRef] [PubMed]

159. Beckman, J.D.; Rollins-Raval, M.A.; Raval, J.S.; Park, Y.A.; Mazepa, M.; Ma, A. Bortezomib for Refractory Immune-Mediated Thrombocytopenia Purpura. Am. J. Ther. 2018, 25, e270-e272. [CrossRef]

160. Newland, A.C.; Sánchez-González, B.; Rejtő, L.; Egyed, M.; Romanyuk, N.; Godar, M.; Verschueren, K.; Gandini, D.; Ulrichts, P.; Beauchamp, J.; et al. Phase 2 study of efgartigimod, a novel FcRn antagonist, in adult patients with primary immune thrombocytopenia. Am. J. Hematol. 2020, 95, 178-187. [CrossRef]

161. Chen, Z.; Guo, Z.; Ma, J.; Ma, J.; Liu, F.; Wu, R. Foxp3 methylation status in children with primary immune thrombocytopenia. Hum. Immunol. 2014, 75, 1115-1119. [CrossRef]

162. Ding, K.; Fu, R.; Liu, H.; Nachnani, D.A.; Shao, Z.-H. Effects of decitabine on megakaryocyte maturation in patients with myelodysplastic syndromes. Oncol. Lett. 2016, 11, 2347-2352. [CrossRef]

163. Zhou, H.; Hou, Y.; Liu, X.; Qiu, J.; Feng, Q.; Wang, Y.; Zhang, X.; Min, Y.; Shao, L.; Liu, X.; et al. Low-dose decitabine promotes megakaryocyte maturation and platelet production in healthy controls and immune thrombocytopenia. Thromb. Haemost. 2015, 113, 1021-1034. [CrossRef] [PubMed]

164. Zhou, H.; Qin, P.; Liu, Q.; Yuan, C.; Hao, Y.; Zhang, H.; Wang, Z.; Ran, X.; Chu, X.; Yu, W.; et al. A prospective, multicenter study of low dose decitabine in adult patients with refractory immune thrombocytopenia. Am. J. Hematol. 2019, 94, $1374-1381$. [CrossRef] [PubMed]

165. Levi, M.; Thachil, J. Coronavirus Disease 2019 Coagulopathy: Disseminated Intravascular Coagulation and Thrombotic Microangiopathy-Either, Neither, or Both. Semin. Thromb. Hemost. 2020, 46, 781-784. [CrossRef] [PubMed]

166. Pavord, S.; Thachil, J.; Hunt, B.J.; Murphy, M.; Lowe, G.; Laffan, M.; Makris, M.; Newland, A.C.; Provan, D.; Grainger, J.D.; et al. Practical guidance for the management of adults with immune thrombocytopenia during the COVID-19 pandemic. Br. J. Haematol. 2020, 189, 1038-1043. [CrossRef] [PubMed]

167. Mahévas, M.; Moulis, G.; Andres, E.; Riviere, E.; Garzaro, M.; Crickx, E.; Guillotin, V.; Malphettes, M.; Galicier, L.; Noel, N.; et al. Clinical characteristics, management and outcome of COVID-19-associated immune thrombocytopenia: a French multicentre series. Br. J. Haematol. 2020, 190, e224-e229. [CrossRef] [PubMed] 